\title{
Characterization and Analysis of Tetranitrate Esters
}

Jimmie C. Oxley; James, L. Smith; Joseph E. Brady, IV; Austin C. Brown

University of Rhode Island, Chemistry Dept; Kingston, RI 02881

\begin{abstract}
Thermal behaviors, vapor pressures, densities, and drop weight impact results, as well as analytical protocols, are reported for three tetranitrate esters: erythritol tetranitrate (ETN), 1,4dinitrato-2,3-dinitro-2,3bis(nitratomethylene) butane (DNTN), and pentaerythritol tetranitrate (PETN). ETN and DNTN both melt below $100^{\circ} \mathrm{C}$ and have ambient vapor pressures comparable to TNT. While LC/MS was shown to be a viable technique for analysis of all three tetranitrate esters, only ETN was successfully analyzed by GC/MS. Performance of these nitrate esters as evaluated in lab using the small-scale explosivity device (SSED) suggested RDX $>>$ DNTN $>$ PETN $>$ ETN. Detonation velocities were calculated using Cheetah 6.0. Since the starting material is now widely available, it is likely that law enforcement will find ETN in future improvised explosive devices. This paper with its analytical schemes should prove useful in identification of this homemade explosive.
\end{abstract}

Keywords: erythritol tetranitrate, ETN, 1,4-dinitrato-2,3-dinitro-2,3bis(nitratomethylene) butane, DNTN, pentaerythritol tetranitrate, PETN, vapor pressure, densities, drop weight impact, thermal behavior, HPLC-HRMS

\section{Introduction}

In recent years there has been growth in use of so-called "homemade" explosives (HME). Preparation of HME can require little synthetic expertise. It can be as simple as mixing oxidizers and fuels as opposed to the preparation and isolation of discrete compounds. When specific characteristics are required terrorists do engage in more complex synthetic procedures. Common approaches include preparations of peroxide based explosives or the nitration of alcohols to form nitrate esters:

$$
\mathrm{R}-\mathrm{OH}+\mathrm{HNO}_{3} \rightarrow \mathrm{R}-\mathrm{ONO}_{2}+\mathrm{H}_{2} \mathrm{O}
$$

Formation of the nitrate ester favors use of either sulfuric acid with concentrated nitric acid $(68 \%)$ or fuming nitric acid $(>86 \%)$. Competing with nitration is the oxidation of the alcohol. 
For example, in the presence of 55\% nitric acid diethylene glycol may be oxidized to di-glycolic acid or cleaved at the ether and oxidized to oxalic acid ${ }^{1}$; with $\leq 95 \%$ nitric acid or a combination of nitric and sulfuric acids, the di-nitrate ester, di-ethylene glycol dinitrate (DEGDN) can be formed $^{2}$. Typically, terrorists and criminals choose to nitrate methanol, ethylene glycol, glycerin, or pentaerythritol. The nitration of erythritol to erythritol tetranitrate (ETN) has been known longer (1849) than that of ethylene glycol (1870) or pentaerythritol (1894). ${ }^{3}$ The nitrate ester ETN had been largely ignored because the erythritol precursor was not readily available. While previously extracted from seaweed, ${ }^{4}$ algae, and lichen, ${ }^{5}$ erythritol is now produced on an industrial scale using microbial techniques. ${ }^{6}$ With the advent of low-carbohydrate diets, erythritol has become available in bulk to the general public. ${ }^{7}$

Recent reports suggest that with availability of erythritol, synthesis of ETN is being targeted by juveniles, criminals and terrorists. ${ }^{8}$ The chemical structure of ETN is similar to the military explosive, PETN. The military and law enforcement require physical properties and other characteristics of ETN as they compare to PETN in order to asses the potential risks associated with its availability. We report the properties and analysis characteristics of ETN herein and compare them to PETN and the recently reported dinitro-tetranitrate ester, (DNTN). ${ }^{9}$ Because of DNTN's low melting point and predicted explosive performance, it is an attractive material for use as a military or commercial explosive. Included is an assessment of ETN's sensitivity to initiation and performance as compared to DNTN and PETN, which has been associated with several terrorist plots, e.g. the Shoe Bomber (2001), Christmas Day Bomb Plot (2009), and Cargo Plane Bomb Plot (2010). ${ }^{10}$

\section{Experimental Section}

\subsection{Preparation of ETN}
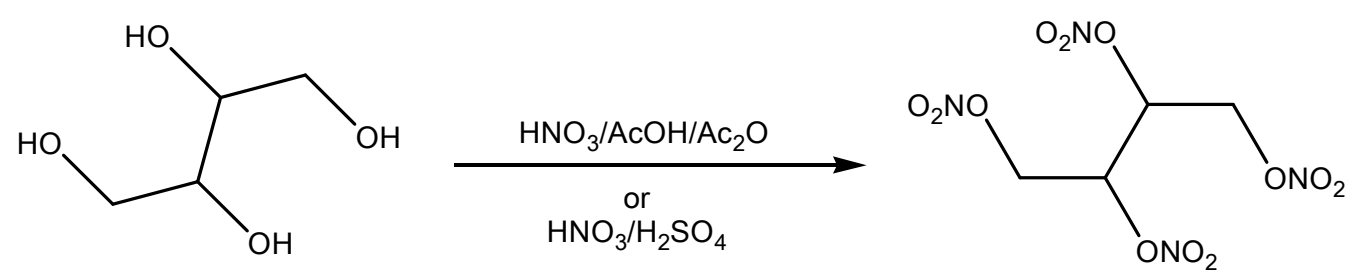

Erythritol tetranitrate (ETN) was prepared by mixed acid nitration. ${ }^{11}$ Erythritol (2.0 g, $0.016 \mathrm{~mol})$ was dissolved in concentrated sulfuric acid $(96 \%, 14.0 \mathrm{~g}, 0.143 \mathrm{~mol})$ in a $25 \mathrm{~mL}$ round bottomed flask at room temperature with stirring. Concentrated sulfuric acid $(96 \%, 1.4 \mathrm{~g}$, 
$0.014 \mathrm{~mol})$ was added to the fuming nitric acid $(98 \%, 14.0 \mathrm{~g}, 0.222 \mathrm{~mol})$ in a $50 \mathrm{~mL}$ round bottomed flask and chilled to $0^{\circ} \mathrm{C}$ with stirring. The erythritol/sulfuric acid mixture was added to the nitric/sulfuric acid mixture over 30 minutes while maintaining the temperature below $10^{\circ} \mathrm{C}$. After addition was complete, the mixture was warmed to $35^{\circ} \mathrm{C}$ and stirred for 1 hour, initially becoming cloudy and nearly opaque after about 15 minutes. The reaction mixture was poured over $400 \mathrm{~mL}$ of shaved ice, filtered, rinsed with copious amounts of distilled water and dried for 1 hour over a vacuum aspirator to yield $3.60 \mathrm{~g}(0.012 \mathrm{~mol}, 75 \%)$ of ETN, $\mathrm{mp}=58$ $59^{\circ} \mathrm{C}$. The product was dissolved in hot methanol, ammonium carbonate was added to neutralize any remaining acid and hot filtered. The recrystallized product had a melting point of $60-61^{\circ} \mathrm{C}$.

Alternatively, ETN may be prepared by nitration with acetyl nitrate. Glacial acetic acid $(25 \mathrm{~mL})$ and acetic anhydride $(25 \mathrm{~mL})$ were added to a $250 \mathrm{~mL}$ round bottom flask. The flask was placed in an ice/water bath and cooled to $0^{\circ} \mathrm{C}$. Fuming nitric acid $(19 \mathrm{~g}, 98 \%)$ was added drop wise, maintaining the temperature below $10^{\circ} \mathrm{C}$. The reaction mixture was allowed to stir for 1 hour and erythritol $(3.02 \mathrm{~g}, 0.0247 \mathrm{~mol})$ was added in small portions. The mixture was stirred for 2 hours at $0^{\circ} \mathrm{C}$, the flask was removed from the ice water bath and stirred for an additional 2 hours. The reaction mixture poured over $200 \mathrm{~mL}$ of ice, the product was filtered, rinsed with copious amounts of water, and allowed to air dry. The resulting crude product $(7.25 \mathrm{~g}, \mathrm{mp} 59.6-$ $61.0)$ was recrystallized from isopropanol $\left(6.34 \mathrm{~g}, 85 \%\right.$ yield, $\left.\mathrm{mp} 60.5-61.5^{\circ} \mathrm{C}\right)$. ETN is soluble in methanol, ethanol, isopropanol, acetone and acetonitrile. Infrared and Raman spectra are shown in Figures 1 and 2.

\subsection{Preparation of DNTN (1,4-dinitrato-2,3-dinitro-2,3bis(nitratomethylene) butane)}
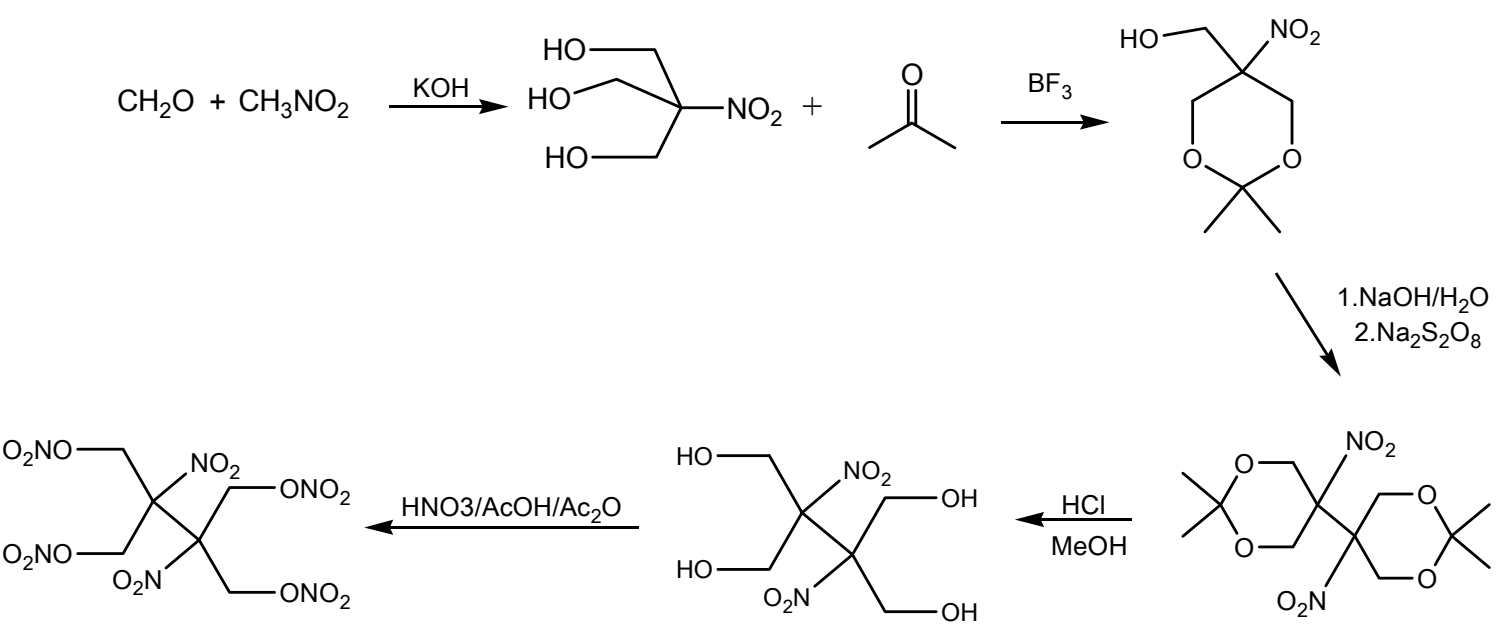
Trismethoxy nitromethane (TMNM) was prepared by combining nitromethane (17.9 g, 0.293 moles $)$ and potassium hydroxide $(0.49 \mathrm{~g}, 8.7 \mathrm{mmol})$ in methanol $(45 \mathrm{~mL})$ and dichloromethane $(2 \mathrm{~mL})$ with stirring in a $200 \mathrm{~mL}$ round bottomed flask. ${ }^{12}$ The flask was cooled in a water bath to $5{ }^{\circ} \mathrm{C}$ and the paraformaldehyde ( $28 \mathrm{~g}, 0.933$ mole) was added gradually over the course of thirty minutes. A condenser was attached to the flask and the mixture was heated to $40^{\circ} \mathrm{C}$ and allowed to react for 2 hours. The mixture was cooled to room temperature and placed in a $-10^{\circ} \mathrm{C}$ freezer for three hours. The precipitate was collected by vacuum filtration and dried overnight in a $50^{\circ} \mathrm{C}$ oven to yield a white solid, $21.45 \mathrm{~g}, 48 \%, \mathrm{mp}=150-154^{\circ} \mathrm{C}$. The TMNM was used without further purification.

The ketal was prepared by the acid catalyzed condensation of TMNM with acetone. ${ }^{13}$ The TMNM (30.21 g, 0.2 moles) and acetone (36.31 g, 0.620 mole) were combined and gently heated until the TMNM dissolved. The mixture was cooled to $20^{\circ} \mathrm{C}$ and the $\mathrm{BF}_{3}(48 \%$ in ether, $34.38 \mathrm{~g}, 0.243$ moles) was added to the mixture in one dose. A condenser was attached and the temperature of the mixture quickly rose to $58^{\circ} \mathrm{C}$. The mixture was stirred for six minutes and poured into $500 \mathrm{~mL}$ of saturated $\mathrm{NaHCO}_{3}$ solution with $100 \mathrm{~mL}$ of shaved ice. The cream colored precipitate $(27.49 \mathrm{~g}, 72 \%)$ was collected by vacuum filtration, rinsed with copious amounts of water, and had a melting point of $130-132^{\circ} \mathrm{C}$. Recrystallization from ethyl acetate or methanol yields a lighter colored product, $\mathrm{mp} 133-134^{\circ} \mathrm{C}$.

The dimerized ketal was prepared by combining water (740 g), sodium hydroxide solution $(50 \%, 49.12 \mathrm{~g}, 0.614$ moles) and the ketal (57.08 g, 0.299 moles) in a $2 \mathrm{~L}$ round bottomed flask. The mixture was heated to $50^{\circ} \mathrm{C}$ and maintained between 50 and $60^{\circ} \mathrm{C}$ for 2.5 hours before cooling to $20^{\circ} \mathrm{C}$. The sodium persulfate $(146.30 \mathrm{~g}, 0.615$ moles) was added and the mixture was stirred at room temperature for 24 hours. Sodium hydroxide solution was used to raise the $\mathrm{pH}$ 11-12 and the precipitate was filtered and washed with cold water. The product (28.09 g, 58\%), was a light tan solid, $\mathrm{mp}=129-130^{\circ} \mathrm{C}$.

The dinitro-tetra-ol was prepared by dissolving the coupled ketal (17.45 g, 0.054 moles) in methanol $(175 \mathrm{~mL})$ and gently bubbling $\mathrm{HCl}$ gas into the solution at room temperature with stirring until the mixture dissolved, approximately 2 minutes. Within five minutes of the addition of the $\mathrm{HCl}$, the mixture became a very dark brown but was still translucent. The reaction vessel was sealed and allowed to react at room temperature for 45 hours. The methanol 
was removed by rotary evaporation, the mixture was triturated with n-pentane and the solid was filtered to yield $8.27 \mathrm{~g}(64 \%)$ of solid cream-colored material, $\mathrm{mp}=100-101^{\circ} \mathrm{C}$.

In a $250 \mathrm{~mL}$ round-bottomed flask, $25 \mathrm{~mL}$ glacial acetic acid and $25 \mathrm{~mL}$ of acetic anhydride were combined. This mixture was cooled to $0^{\circ} \mathrm{C}$ with stirring and fuming nitric acid (98\%, $19 \mathrm{~g}, 0.299$ moles) was added while maintaining the temperature between $0-10^{\circ} \mathrm{C}$. After addition of the nitric acid was complete, the mixture was allowed to react with stirring wile maintaining the temperature at approximately $0^{\circ} \mathrm{C}$. The tetra-ol was $(5.98 \mathrm{~g}, 0.025$ moles $)$ added to the mixture over the course of 30 minutes and the mixture was stirred for an additional 2.5 hours at $0^{\circ} \mathrm{C}$. The mixture was poured over $200 \mathrm{~mL}$ of ice/water, the solid was filtered, and washed with $200 \mathrm{~mL}$ of $1 \% \mathrm{Na}_{2} \mathrm{CO}_{3}$ solution, followed by cold water. After air-drying overnight, the crude material, $7.86 \mathrm{~g}(75 \%$ yield $), \mathrm{mp}=81-84^{\circ} \mathrm{C}$, was recrystallized from reagent alcohol to yield a white solid, $\mathrm{mp}=84-85^{\circ} \mathrm{C}$. DNTN was found to be soluble in methanol, ethanol, isopropanol, acetone and acetonitrile. Infrared and Raman spectra are shown in 3 and 4.

The PETN used in this study was obtained from obtained from commercial sources.

\section{Analyses}

\subsection{HPLC/HRMS}

Both the crude (mixed acid preparation) and recrystallized ETN were analyzed using high performance liquid chromatography (HPLC) with atmospheric pressure ionization and highresolution mass spectrometry (HRMS). The strongly electron-withdrawing nature of the nitro and nitrate ester moieties makes these molecules vulnerable to adduct formation with the mobile phase and/or impurities in the mobile phase or elsewhere in the system, further complicating analysis. However, this feature may be exploited by introducing an additive into the system that generates nucleophilic ions. ${ }^{14}$ The introduction of chlorinated compounds $\left(\mathrm{CH}_{2} \mathrm{Cl}_{2}, \mathrm{CHCl}_{3}\right.$, $\mathrm{CCl}_{4}, \mathrm{NH}_{4} \mathrm{Cl}$ ) into the mobile phase is known to cause the preferential formation of chlorinated adducts with nitrate esters $\left[\mathrm{R}-\mathrm{O}-\mathrm{NO}_{2}+\mathrm{Cl}\right]^{-}$, nitramines $\left[\mathrm{R}-\mathrm{N}-\mathrm{NO}_{2}+\mathrm{Cl}\right]^{-}$, and to de-protonate nitro-aromatics $\left[\mathrm{Ar}-\mathrm{NO}_{2}-\mathrm{H}\right]^{-15}$ Carbon tetrachloride was added to the mobile phase in this study to generate chloride adducts.

The mass spectrometer was a Thermo Scientific Exactive operated in the negative ion mode using APCI. To minimize decomposition during analysis, the vaporizer was set at $200^{\circ} \mathrm{C}$ and capillary was set to $125^{\circ} \mathrm{C}$. The discharge current was $80 \mu \mathrm{A}$, and the sheath gas and 
auxiliary gas were operated at 35 and 10 arbitrary units, respectively. When directly injected into the ionization source via syringe pump, the flow rate was $15 \mu \mathrm{L} / \mathrm{min}$, and the material was dissolved in a 50:50 methanol-water solution with $0.25 \%$ carbon tetrachloride. The resolution was set to high $(50,000$ at $2 \mathrm{~Hz})$, and the maximum injection time was $250 \mathrm{~ms}$. Separation by HPLC was performed by gradient elution. The solvents were water (A) and methanol w/ $0.25 \%$ $\mathrm{CCl}_{4}, \mathrm{v} / \mathrm{v},(\mathrm{B})$. The flow rate was held constant at $300 \mu \mathrm{L} / \mathrm{min}$. The mobile phase was changed from $90 \%$ A, $10 \%$ B to $10 \%$ A, $90 \%$ B over 7.5 minutes, followed by $90 \%$ A, $10 \%$ B for 2.5 minutes. Samples $(10 \mu \mathrm{L})$ of the crude and recrystallized product were analyzed at the $1 \mathrm{mg} / \mathrm{mL}$ level using a Hypersil GOLD Phenyl column from Thermo Scientific (dimensions $50 \mathrm{~mm}$ x 2.1 mm with particle size of $3 \mu \mathrm{m}$ ).

A portion of twice recrystallized ETN was dissolved in 50/50 methanol/water to prepare a $1 \mathrm{mg} / \mathrm{mL}$ solution. When this solution was directly infused into the source for one minute, there were five prominent signals (Table 1, Fig. 5A). While the expected $\left[\mathrm{ETN}+{ }^{35} \mathrm{Cl}\right]^{-}$was found, signals corresponding to erythritol dinitrate (EdiN) and erythritol trinitrate (EtriN), each with one ${ }^{35} \mathrm{Cl}^{-}$, were also observed. In addition, a nitrate adduct $\left[\mathrm{ETN}+\mathrm{NO}_{3}\right]^{-}$and an adduct with a mass corresponding to $[\mathrm{ETN}+\mathrm{OH}]^{-}$were detected. More likely than the formation of an $[\mathrm{ETN}+\mathrm{OH}]^{-}$ adduct is the loss of one $\mathrm{NO}_{2}$ followed by the addition of $\mathrm{HNO}_{3}$, [ETN $\left.-\mathrm{NO}_{2}+\mathrm{HNO}_{3}\right]^{-}$. The formation of nitric acid adducts during negative mode LC/MS-APCI has been reported elsewhere. $^{16}$

After finding what appeared to be the di- and tri-nitrated products during direct infusion experiments, the twice-recrystallized ETN sample and a crude sample, both at a concentration of $1 \mathrm{mg} / \mathrm{mL}$, were separated using HPLC and analyzed by HRMS. The twice-recrystallized sample was run in triplicate and showed only one chromatographic peak, eluting at 6.74 minutes (Fig. 6, 5B). While the ions found in the mass spectrum for this peak were identical to those found during direct infusion, the relative abundance of each mass was significantly different (Table 1, 2). The concentration of the sample also affected the distribution of adducts. When the concentration of ETN was reduced from 1 to $0.01 \mathrm{mg} / \mathrm{mL}$, the $\left[\mathrm{ETN}+\mathrm{NO}_{3}\right]^{-}$signal was greatly reduced and the $\left[\mathrm{ETN}-\mathrm{NO}_{2}+\mathrm{HNO}_{3}\right]^{-}$was not found. When the concentration of ETN was reduced to $0.001 \mathrm{mg} / \mathrm{mL}$, [ETN $\left.+\mathrm{NO}_{3}\right]^{-}$was not found (Table 3). Since the decomposition of ETN is the most likely source of the nitrate ion, as the concentration of ETN decreased, the amount of nitrate also decreased as did the amount of $\left[\mathrm{ETN}+\mathrm{NO}_{3}\right]^{-}$formed. 
When the crude ETN (m.p. $=58-59^{\circ} \mathrm{C}$ ), was separated by HPLC, two chromatographic peaks were observed. Examination of the first peak (5.37 min, Fig.6) revealed only two signals of interest. The most prominent signal in the mass spectrum was found to have a mass corresponding to $\left[\text { EtriN }+{ }^{35} \mathrm{Cl}\right]^{-}(\mathrm{m} / \mathrm{z} \sim 292$, Fig. 5C), while the much smaller signal corresponded to $\left[\mathrm{EdiN}+{ }^{35} \mathrm{Cl}\right]^{-}$. The second chromatographic peak $(\sim 6.5 \mathrm{~min}$, Fig. 6$)$ had the same retention time and fragmentation pattern as the twice-recrystallized ETN. The integrated signal of first peak, tentatively assigned as the trinitrated product, was about $3 \%$ of the total area of that of ETN.

When PETN was subject to mass spectrometry under the same conditions used for ETN, four major signals corresponding to $\left[\mathrm{PETN}+\mathrm{NO}_{3}\right]^{-},[\mathrm{PETN}+\mathrm{Cl}]^{-},[\mathrm{PETriN}+\mathrm{Cl}]^{-}$, and $[\mathrm{PEDiN}$ $+\mathrm{Cl}^{-}$were observed. Like ETN, the relative abundance of these ions was shown to be concentration dependent (Table 3). Interestingly, DNTN did not exhibit fragmentation analogous to ETN or PETN. Aside from the anticipated [DNTN $+\mathrm{Cl}]^{-}$, only $\left[\mathrm{DNTN}+\mathrm{NO}_{3}\right]^{-}$ was found and the relative amount of amount of each adduct was also found to be concentration dependent (Table 3).

\subsection{GC/MS}

The analysis of explosives, particularly nitrate esters, by gas chromatography is known to be problematic ${ }^{17}$. Therefore, optimization of the conditions for analysis of ETN by gas chromatography-electron impact mass spectrometry (GC-MS) was necessary. An Agilent 6890 gas chromatograph with an Agilent 5973i mass selective detector was used. The column was a DB5-MS, with a nominal diameter of $250 \mu \mathrm{m}$ and a film thickness of $0.250 \mu \mathrm{m}$, cut to 10 meters. The column was cut to 10 meters after numerous unsuccessful attempts to analyze the material with a 30-meter column. Presumably, a shorter column improved sensitivity by reducing the amount of time the analyte spent in the column, simultaneously reducing the thermal decomposition of the analyte. The inlet was a split/splitless inlet from Agilent Technologies operated in either the split (5:1) or splitless mode; the inlet temperature was varied from 100 to $250^{\circ} \mathrm{C}$. The carrier gas was ultra-high purity helium, and the flow rate was either 1.5 or 2.0 $\mathrm{mL} / \mathrm{min}$. Initial temperature of the oven was either 50 or $100^{\circ} \mathrm{C}$, and ramp rates of 10 and $20^{\circ} \mathrm{C} / \mathrm{min}$ were used. The temperature of the transfer line was varied between 100 and $300^{\circ} \mathrm{C}$. The conditions were varied iteratively, and thirty-one separate sets of conditions were screened. 
The mass spectrometer was operated with a solvent delay of 1 minute and was tuned daily using Agilent's “STUNE.U” program.

The optimized conditions were a 5:1 split at $100{ }^{\circ} \mathrm{C}$ at the inlet, $1.5 \mathrm{~mL} / \mathrm{min}$ flow rate and transfer line temperature of $200{ }^{\circ} \mathrm{C}$. The oven was held at $50^{\circ} \mathrm{C}$ for 2 minutes before ramping to $300^{\circ} \mathrm{C}$ at a rate of $20^{\circ} \mathrm{C} / \mathrm{min}$. The ETN eluted as a single peak at $\sim 7.3$ minutes. Varying the oven ramp rate, initial oven temperature or carrier gas flow rate varied the retention time with no significant effect on the signal. The mass spectrum of ETN revealed considerable thermal decomposition, and the parent peak was not observed in any of the trials. The three most prominent peaks in the mass spectrum were 30,46, and $76 \mathrm{~m} / \mathrm{z}$, most likely corresponding to $\mathrm{NO}, \mathrm{NO}_{2}$ and $\mathrm{CH}_{2} \mathrm{NO}_{3}$. Other peaks and their tentative assignments are given in Table 4. When holding all other conditions constant, it was observed that as the temperature of the transfer line increased, the relative abundance of $\mathrm{NO}$ with respect to $\mathrm{NO}_{2}$ increased, most likely the result of the thermal decomposition of $\mathrm{NO}_{2}$ to $\mathrm{NO}$. If the temperature of the inlet was $150^{\circ} \mathrm{C}$ or above, ETN partially decomposed at the inlet elevating the baseline, reducing the size of the main chromatographic peak and causing the appearance of multiple peaks in the chromatogram (Fig. 7). As the inlet temperature was increased, the decomposition peaks increased in size with respect to the ETN peak. When the inlet temperature was $250^{\circ} \mathrm{C}$ or higher, the ETN decomposed completely. The chromatogram was identical to an injection of neat methanol, presumably because the decomposition products were molecules small enough to elute before the solvent delay. Seven different concentrations of ETN between 0.0001 and $1000 \mathrm{mg} / \mathrm{L}$ were prepared and analyzed by GC/MS to evaluate the sensitivity of the technique. The signal for ETN was plainly apparent without magnification or background subtraction at the $0.005 \mathrm{mg} / \mathrm{L}$ level but did not appear to be present at the $0.001 \mathrm{mg} / \mathrm{L}$ level. A plot of the ions 30, 46, 60 and 76 at the 0.001 $\mathrm{mg} / \mathrm{L}$ level yielded overlapping signals with the correct retention time and with $\mathrm{S} / \mathrm{N}>>3$. These ions show promise as candidates for the low-level detection of ETN by GC/MS using selective ion monitoring or tandem mass spectrometry.

Using identical conditions to those successfully used to examine ETN, multiple attempts were made to analyze DNTN and PETN by GC/MS. DNTN eluted as a broad hump, while PETN eluted as a well-defined peak, with a height and area disproportionally small to the amount of PETN in the solution. The major fragments found for DNTN using the method 
described for ETN are, in order of intensity, m/z 30, 46, and 114 while the major fragments for PETN are 46, 30, and 76.

\subsection{Differential Scanning Calorimetry}

Samples $(0.190-0.490 \mathrm{mg})$ were flame sealed in glass micro-ampoules $(9.5 \mathrm{~mm} \times 1.0$ $\mathrm{mm}$ ) and examined using a TA Instruments Q100 DSC. The cell resistance, cell capacitance, and cell constant were obtained by calibrating against sapphire, and the temperature was calibrated using indium. All experiments were performed under a stream of ultra-high purity nitrogen at 50 $\mathrm{mL} / \mathrm{min}$. The values shown in Table 5 indicate that a single endothermic melt and exothermic decomposition were observed for ETN, PETN, and DNTN. Figures 8, 9, and 10 show typical DSC traces at $10^{\circ}$ minutes. However, in a few sample of ETN a small exothermic deviation from baseline was observed immediately after the first exotherm (Fig. 8). Since the DSC tube was sealed, all the decomposition products were retained in the glass capillary tube, and the second exotherm must be the result of a secondary oxidation involving them.

The activation energies of thermal decomposition and the Arrhenius pre-exponential factors of ETN, DNTN, and PETN were tabulated by employing the methods outlined in ASTM E 698-05 using equations (1) and (2) and using the individual data which is shown in average in Table 5.

$$
\begin{gathered}
E_{a}=R\left(\frac{d\left[-\ln \left(\frac{\beta}{T^{2}}\right)\right]}{d\left[\frac{1}{T}\right]}\right)(1) \\
Z=\frac{\beta E e^{\frac{E}{R T}}}{R T^{2}}(2)
\end{gathered}
$$

where $\mathrm{R}$ is the gas constant, $\beta$ is the heating rate in $\mathrm{K}, \mathrm{T}$ is the maximum temperature for the exothermic decomposition in Kelvin and $Z$ is the Arrhenius pre-exponential factor. Experiments were carried at out at $\beta=1-10 \mathrm{~K} / \mathrm{min}$. Figures 11,12 , and 13 show the plots yielding activation energies for ETN, DNTN, and PETN, respectively. The activation energies and Arrhenius preexponential factors, calculated using $\beta=5 \mathrm{~K} / \mathrm{min}$, thus determined are shown in Table 6 .

\subsection{Thermogravimetric analysis and vapor pressure determinations}


Thermogravimetric analysis (TGA) was used to examine the thermal decomposition of ETN, PETN, and DNTN on a Thermal Analysis Q5000. The samples, 8 to $10 \mathrm{mg}$, were loaded into $100 \mu \mathrm{L}$ open platinum pans. The analytical run consisted of an initial, isothermal hold at ambient operating temperature, 35 to $40{ }^{\circ} \mathrm{C}$, for five minutes with a flow to the balance of 20 $\mathrm{mL} / \mathrm{min}$ and $50 \mathrm{~mL} / \mathrm{min}$ to the furnace of ultra high purity nitrogen. The flows to the balance and furnace were then reduced to 10 and $25 \mathrm{~mL} / \mathrm{min}$, respectively, and the furnace was ramped at a rate of $10{ }^{\circ} \mathrm{C} / \mathrm{min}$ to $300{ }^{\circ} \mathrm{C}$. The experiment was repeated in quadruplicate and representative thermograms are shown in Figure 14.

The thermogram showed a very gradual mass loss for ETN between 40 and $145^{\circ} \mathrm{C}$, losing $1 \%$ of the total mass. Above $145^{\circ} \mathrm{C}$, the mass loss was more rapid but still steady; no ETN remained at $205^{\circ} \mathrm{C}$. The rate of mass loss for PETN was also steady but more rapid than that of ETN. Between $165^{\circ} \mathrm{C}$ and $199^{\circ} \mathrm{C}, 95 \%$ of the PETN was lost, with complete decomposition by $300^{\circ} \mathrm{C}$. The majority of DNTN mass loss occurred between $146^{\circ} \mathrm{C}$ and $191^{\circ} \mathrm{C}$, dropping from $99 \%$ to $18 \%$. At $300^{\circ} \mathrm{C}, 8 \%$ of the original mass of DNTN remained.

An isothermal gravimetric technique has been reported as a method for measuring of enthalpy of sublimation and vapor pressure. ${ }^{18,19} \mathrm{~A}$ material of known vapor pressure, e.g. benzoic acid, is held at constant temperature and the mass loss is measured per unit time. The experiment is repeated at multiple temperatures in order to calibrate the TGA for the purposes of determining the Antoine coefficients of an unknown material. Benzoic acid, 9-11 mg, was loaded into a $110 \mu \mathrm{L}$ open platinum pan; the furnace was closed and held at fixed temperatures for 250 minutes. The flow to the furnace was $80 \mathrm{~mL} / \mathrm{min}$, the flow to the balance was 20 $\mathrm{mL} / \mathrm{min}$, and the purge gas was ultra high purity nitrogen.

The vapor pressure of benzoic acid at various temperatures is available (http://webbook.nist.gov). The natural logarithm of its vapor pressure was plotted versus the natural logarithm of the sublimation rate (Fig. 15). The equation of the line in this plot takes the form

$$
\ln P=A \ln \left(\frac{\mathrm{d} m}{\mathrm{~d} t}\right)+B
$$

where $\mathrm{d} m / \mathrm{d} t$ is the sublimation rate in $\mathrm{mg} / \mathrm{min}, P$ is the vapor pressure in Pascals, and $A$, the slope, and $B$, the intercept, are the pseudo-Antoine coefficients. For benzoic acid and the experimental conditions used in this study, the coefficients are $A=0.9542$ and $B=8.3534$. The 
sublimation rates at specific temperatures of PETN, ETN, and DNTN were determined experimentally and used with the pseudo-Antoine equation above to extrapolate the vapor pressures. The vapor pressures at these temperatures were used to construct Clapeyron plots (Figs. 16, 17). Extrapolating to $25^{\circ} \mathrm{C}$, the vapor pressures for the three nitrate esters were determined along with their enthalpy of sublimation. The slope of the line in a Clapeyron plot is the enthalpy of sublimation $\left(\Delta \mathrm{H}_{\text {sub }}\right)$ divided by the gas constant. This is the first report of vapor pressures for ETN and DNTN. Vapor pressure and sublimation enthalpy of PETN have previously been reported as $1.78 \times 10^{-5} \mathrm{~Pa},{ }^{20}$ and $150.4 \mathrm{~kJ} / \mathrm{mol},{ }^{21}$ respectively; these values compare well with those found herein (Table 6).

\subsection{Density}

The density of mono-molecular explosives is known to have a strong effect on the performance of energetic materials. The densities of ETN, PETN and DNTN were measured using a Micromeritics AccuPyc II helium gas pycnometer. The instrument was calibrated according to the manufacturer's instructions using a steel sphere of known mass and volume. Samples were prepared by filling the provided crucibles to $50-75 \%$ of capacity with the material and recording the mass of sample. The cell was purged with helium ten times and ten volume measurements were made. The calibration was verified using $\mathrm{BaCl}_{2} \cdot 2 \mathrm{H}_{2} \mathrm{O}$ and the value, 3.1048 $( \pm 0.0019) \mathrm{g} / \mathrm{cm}^{3}$, found to be close to literature value, $3.097 \mathrm{~g} / \mathrm{cm}^{3}$. The densities of the

materials discussed in this study were measured. ETN was found to have density 1.7219 $( \pm 0.0025) \mathrm{g} / \mathrm{cm}^{3}$; DNTN density $1.8238( \pm 0.0016) \mathrm{g} / \mathrm{cm}^{3}$; and PETN density $1.7599( \pm 0.0006)$ $\mathrm{g} / \mathrm{cm}^{3}$ (Table 6).

\subsection{Impact Sensitivity}

An in-house drop-weight impact sensitivity apparatus and the Bruceton Method were used to compare the sensitivities of ETN, PETN and DNTN to initiation from impact. The apparatus was modeled after the "LLNL Small-Scale Drop-Hammer Impact Sensitivity Test."22 The test material (35 +/- $1 \mathrm{mg}$ ) was loaded onto a 1 inch square piece of 120-grit sandpaper and the sample was placed under a cylindrical, steel striker. A steel weight (4 kg) attached to a fixed, vertical rail was raised to a known height and released. The height of the hammer was varied in $1 \mathrm{~cm}$ increments until at least 20 measurements could be collected at 6 consecutive heights. A 
"go" was characterized by a loud report and significant damage to the sandpaper, whereas after a "no-go," the sandpaper was intact and the material remained. By applying the Bruceton Method, the height at which the probability of explosion is 0.5 , or " $\mathrm{Dh}_{50}$ ", may be determined. These experiments showed that ETN $(24.0 \mathrm{~cm})$ is more sensitive to impact than PETN $(25.2 \mathrm{~cm})$ while DNTN $(27.7 \mathrm{~cm})$ is less sensitive than both (Table 6).

\subsection{Small-Scale Explosivity Testing}

The performance of ETN was compared to PETN, RDX and DNTN using a small-scale explosivity device (SSED) ${ }^{23-27}$ This technique has been used to compare explosive performance of laboratory-scale quantities of materials using the metric of the weight of intact cartridge remaining. The cartridge employed was a British .303 rifle cartridge, and the fragment to be weighed was the base and all metal remaining attached to it. The explosive, exactly $2 \mathrm{~g}$, was loaded into the brass cartridge, and the depth measured in order to calculate the volume and tap density. An RP-3 (29 mg of PETN) exploding bridge wire (EBW) detonator was placed so that the bottom of the detonator was just below the surface $(2-4 \mathrm{~mm})$ of the material. The loaded cartridge was secured in a 2" thick one liter steel bolted closure vessel and electronically initiated

from a remote location. After detonation, the base of the cartridge, the largest and the only readily identifiable portion remaining, was recovered and sonnicated in water (15 minutes) followed by an acetone rinse ( 15 minutes), dried in a $125^{\circ} \mathrm{C}$ oven, and weighed to determine the fraction remaining. As seen in Table 7, the relative explosive power of the materials was found to be $\mathrm{RDX}>>$ DNTN $>$ PETN $>$ ETN .

Cheetah $6.0^{28}$ was used to predict the detonation velocities of the materials using literature values for the heats of formation ${ }^{3,9}$ and calculating at two different densities. For the tetranitrate esters density as measured by pycnometry and reported above were used. For RDX and EGDN literature values were input. ${ }^{28,29}$ To make calculations more comparable to SSED, the nominal tap density of $0.69 \mathrm{~g} / \mathrm{cm}^{3}$ was also used to calculate detonation velocities. Results of this latter calculation again indicate RDX performs much better than the nitrate esters.

\section{Conclusion}

The physical properties and analyses of three tetranitrate esters have been measured and compared. ETN and DNTN both melt below $100^{\circ} \mathrm{C}$, and unlike PETN, they are stable above 
their melting points $\left(60\right.$ and $85^{\circ} \mathrm{C}$, respectively). As the low melting point suggests, they have significant vapor pressures at ambient conditions. In fact, their $25^{\circ} \mathrm{C}$ vapor pressures (ETN, 3.19 x $10^{-3}$; DNTN, $4.10 \times 10^{-3} \mathrm{~Pa}$ ) as measured by isothermal TGA, are slightly higher than those reported for TNT (.0004 to $0.0007 \mathrm{~Pa}$ at $25^{\circ} \mathrm{C}$, Table 2, reference 30 ). While LC/MS was shown to be a viable technique for analysis of all three tetranitrate esters, only ETN was successfully analyzed by GC/MS. Initial DSC kinetics suggested the thermal stability of ETN and DNTN is poorer than PETN, but the molecules exhibit a more favorable oxygen balance than PETN.

Performance of these nitrate esters was tested in the lab using the small-scale explosivity device (SSED) $)^{23-27}$ and comparing the fraction of the holder remaining to that left by RDX. By that test the most powerful explosive was RDX: $\quad$ RDX $>>$ DNTN $>$ PETN $>$ ETN. Performance was also judged by calculating detonation velocities using the densities measured in this study. Here the denser DNTN performed better than the other three explosives. Detonation velocities calculated for all four explosives and ethylene glycol dinitrate (EGDN) at the density used in the $\operatorname{SSED}\left(\sim 0.69 \mathrm{~g} / \mathrm{cm}^{3}\right)$ yielded velocities ranging from $4.7 \mathrm{~km} / \mathrm{s}$ to $4.0 \mathrm{~km} / \mathrm{s}$ :

$$
\text { RDX }>>\text { PETN }>\text { EGDN } \sim \text { DNTN }>\text { ETN. }
$$

Interestingly, DNTN and EGDN have identical oxygen balances and almost identical detonation velocities when calculated at same density.

\section{Acknowledgements}

The authors wish to thank the Department of Homeland Security for funding via Cooperative agreement \# 2008-ST-061-ED000 through the University Programs Center of Excellence as well as through the Science \& Technology Division.

\section{References}

[1] C. Y. Shen, D. A. Ruest, Production of Diglycolic Acid by Nitric Acid Oxidation of Diethylene Glycol, Ind. Eng. Chem. Process Des. Dev. 1980, 19, 401-404

[2] T. Urbański, Chemistry and Technology of Explosives, 1965, Pergamon Press, Oxford

[3] B. T. Fedoroff, O.E Sheffield, Encyclopedia of Explosives and Related Items, Vol 5. E124125; Picatinny Arsenal, Dover, NJ, 1972.

[4] J.P. Agrawal, R. Hodgson, Organic Chemistry of Explosives, John Wiley \& Sons Ltd., West Sussex, England 2007, p. 89. 
[5] T. L. Davis, Chemistry of Powder and Explosives, Angriff Press, Hollywood, CA, 1943, p235

[6] Lin et al., Erythritol-Producing Moniliella Strains, U.S. Patent 6916639 2005, Food Industry Research and Development Institute, Taiwan

[7] http://www.amazon.com/Now-Foods-Erythritol-1-lbs/dp/B000Z978SS ; assessed Feb. 2011

[8] [a] http://www.thevillagenews.com/story/52538/, [b] www.gazettenet.com/2009/05/23/ trialopens-amherst-teen-explosives-case?SESSf5277b9c6cedda122d4f2e4a4a4df338=gnews

[9] D. E. Chavez, M. A. Hiskey, D. L. Naud, D. Parrish, Synthesis of an Energetic Nitrate Ester. Angew. Chem., Int. Ed. 2008, 47, 8307-8309.

[10][a] http://www.time.com/time/world/article/0,8599,203478-4,00.html, [b] http://articles. cnn. com/2009-12-29/justice/airline.terror.attempt.petn_1 umar-farouk-abdulmutallab-petnexplosive, [c] www.guardian.co.uk/world/2010/nov/01/petn-explosive-airport-cargo-scanners

[11] F. H. Bergeim Production of Erythritol Tetranitrate, U.S. Patent 1691954 1928, E. I. Du Pont De Nemours \& Company, USA.

[12] Bourguignon et al., Preparation of Tris(hydroxymethyl)aminotmethane, U.S. Patent 4233245 1980, Societe Chimique de La Grande Paroisse, Azote et Produits Chimiques, Paris, FR

[13] G. B. Linden, M.H. Gold, Preparation of 2- and 5-Substituted-1,3-Dioxanes, J. Org. Chem. 1956, 21, 1175.

[14] R.F. Reich, R.A. Yost, Trace Detection and Quantitation of Explosives Using LC/APCIMS, Proceedings of the $49^{\text {th }}$ ASMS Conference on Mass Spectrometry and Allied Topics, Chicago, Illinois, 27-31 May 2001

[15] X. Zhao, J. Yinon, Identification of nitrate ester explosives by liquid chromatographyelectrospray ionization and atmospheric pressure chemical ionization mass spectrometry, $J$. Chromatogr., A 2002, 977(1), 59-68.

[16] J. Almog, G. Burda, Y. Shloosh, S. Abramovich-Bar, E. Wolf, T. Tamiri, Recovery and Detection of Urea Nitrate in Traces, J Forensic Sci 2007, 52(6), 1284-1290.

[17] J. Yinon, S. Zitrin, Modern Methods and Applications in Analysis of Explosives, John Wiley \& Sons Ltd, England, 1996, p. 123.

[18] J.C. Oxley, J.L. Smith, J. Brady, S. Naik, Determination of Urea Nitrate and Guanidine Nitrate Vapor Pressures by Isothermal Thermogravimetry, Propellants, Explos. Pyrotech. 2010, 35(3), 278-283.

[19] M. Xie, T. Ziemba, M. Maurin, Sublimation characterization and Vapor Pressure Estimation of an HIV Nonnucleoside Reverse Trascriptase Inhibitor using Thermogravimetric Analysis, AAPS Phram Sci Tech. 2003, 4 (2), Article 23. 
[20] F.T. Crimmins, The Vapor Pressure of Pentaerythritoltetranitrate (PETN) in the Temperature Range of 50 to 98 Degrees Centigrade, Lawrence Radiation Laboratory, UCRL50704, Jul, 1969.

[21] R.C. Cundall, Vapour Pressure Measurments on Some Organic High Explosives, J. Chem. Soc., Faraday Trans. 1, 1978, 74, 1339-1345

[22] R. L. Simpson, M. F. Foltz, LLNL Small-Scale Drop-Hammer Impact Sensitivity Test, Lawrence Livermore National Laboratory, Livermore, CA, 1995.

[23] J. C. Oxley, J. L. Smith, E. Resende, Determining Explosivity Part II: Comparison of Small-Scale Cartridge Tests to Actual Pipe Bombs, J Forensic Sci 2001, 46(5), p. 1070-1075.

[24] J. Oxley, J. Smith, E. Rogers, E. Resende, A. Mostafa, Small-Scale Explosivity Testing. J. Energetic Mater. 1999; 17: 331-343.

[25] D.P. Lidstone, The Assessment of Explosive Performance by Means of a Cartridge Case Deformation Test. RARDE Memorandum 15/69.

[26] A.M. Lowe, Cartridge Case Test Validation. DRA Report, November 1995.

[27] A.M. Lowe, R. Hilley, Cartridge Case Deformation Test J. Energetic Mater. 1998; 16/4: 289-307.

[28] S. Bastea, Fried L.E., K.R. Glaesemann, W. M. Howard, I-F.W. Kuo, P.C. Souers, P.A. Vitello, Cheetah 6.0, User's Manual, Lawrence Livermore National Laboratory, 2010.

[29] T.R. Gibbs, A. Popolato; LASL Explosive Property Data UC Press, Berkeley, 1980 p. 133.

[30] Oxley, J.C.; Smith, J.L.; Moran, J.; Shinde, K. "Determination of the Vapor Density of Triacetone Triperoxide (TATP) Using A Gas Chromatography Headspace Technique" Propellants, Explosives, Protechnics, 2005, 30.2, 127-130. 
Table 1. Relative MS abundances of adducts formed during the direct injection of ETN. (based on the average of at least three runs)

\begin{tabular}{c|c|c|c} 
Mass $(\mathrm{m} / \mathrm{z})$ & $\begin{array}{c}\text { relative } \\
\text { abundance }(\%)\end{array}$ & Ion & Formula \\
\hline 363.98665 & 100 & {$\left[\mathrm{ETN}+\mathrm{NO}_{3}\right]^{-}$} & $\mathrm{C}_{4} \mathrm{H}_{6} \mathrm{O}_{15} \mathrm{~N}_{5}$ \\
\hline 319.00145 & 50.9 & {$\left[\mathrm{ETN}-\mathrm{NO}_{2}+\mathrm{HNO}_{3}\right]^{-}$} & $\mathrm{C}_{4} \mathrm{H}_{7} \mathrm{O}_{13} \mathrm{~N}_{4}$ \\
\hline 336.96772 & 37.9 & {$\left[\mathrm{ETN}+{ }^{35} \mathrm{Cl}\right]^{-}$} & $\mathrm{C}_{4} \mathrm{H}_{6} \mathrm{O}_{12} \mathrm{~N}_{4} \mathrm{Cl}$ \\
\hline 291.98261 & 22.4 & {$\left[\mathrm{EtriN}+{ }^{35} \mathrm{Cl}\right]^{-}$} & $\mathrm{C}_{4} \mathrm{H}_{7} \mathrm{O}_{10} \mathrm{~N}_{3} \mathrm{Cl}$ \\
\hline 246.99722 & 4.2 & {$\left[\mathrm{EdiN}+{ }^{35} \mathrm{Cl}\right]^{-}$} & $\mathrm{C}_{4} \mathrm{H}_{8} \mathrm{O}_{8} \mathrm{~N}_{2} \mathrm{Cl}$
\end{tabular}

Table 2. Relative MS Abundance of adducts observed by HPLC-HRMS

\begin{tabular}{c|c|c|c} 
Mass (m/z) & $\begin{array}{c}\text { relative } \\
\text { abundance }(\%)\end{array}$ & Ion & Formula \\
\hline 336.96779 & 100 & {$\left[\mathrm{ETN}+{ }^{35} \mathrm{Cl}\right]^{-}$} & $\mathrm{C}_{4} \mathrm{H}_{6} \mathrm{O}_{12} \mathrm{~N}_{4} \mathrm{Cl}$ \\
\hline 291.98274 & 56 & {$\left[\text { EtriN }+{ }^{35} \mathrm{Cl}\right]^{-}$} & $\mathrm{C}_{4} \mathrm{H}_{7} \mathrm{O}_{10} \mathrm{~N}_{3} \mathrm{Cl}$ \\
\hline 363.98680 & 35 & {$\left[\mathrm{ETN}+\mathrm{NO}_{3}\right]^{-}$} & $\mathrm{C}_{4} \mathrm{H}_{6} \mathrm{O}_{15} \mathrm{~N}_{5}$ \\
\hline 246.99731 & 16 & {$\left[\mathrm{EdiN}+{ }^{35} \mathrm{Cl}\right]^{-}$} & $\mathrm{C}_{4} \mathrm{H}_{8} \mathrm{O}_{8} \mathrm{~N}_{2} \mathrm{Cl}$ \\
\hline 319.00157 & 13 & {$\left[\mathrm{ETN}-\mathrm{NO}_{2}+\mathrm{HNO}_{3}\right]^{-}$} & $\mathrm{C}_{4} \mathrm{H}_{7} \mathrm{O}_{13} \mathrm{~N}_{4}$
\end{tabular}

Table 3. Relative abundance of adducts formed during HPLC-HRMS analysis as a function of ETN, DNTN, or PETN concentration (average of 3 runs per concentrations)

\begin{tabular}{|c|c|c|c|}
\hline \multirow{2}{*}{ Species } & \multicolumn{3}{|c|}{ Concentration (mg/L) } \\
\hline & 1000 & 10 & 1 \\
\hline$[\mathrm{ETN}+\mathrm{Cl}]^{-}$ & 100 & 100 & 100 \\
\hline [ETriN + Cl] $^{-}$ & 56 & 17 & 18 \\
\hline$\left[\mathrm{ETN}+\mathrm{NO}_{3}\right]-$ & 35 & 2 & 0 \\
\hline$\left[\mathrm{ETN}-\mathrm{NO}_{2}+\mathrm{HNO}_{3}\right]^{-}$ & 13 & 0 & 0 \\
\hline$[\mathrm{EDiN}+\mathrm{Cl}]^{-}$ & 16 & 5 & 7 \\
\hline [DNTN + Cl] $^{-}$ & 19 & 100 & 100 \\
\hline$\left[\mathrm{DNTN}+\mathbf{N O}_{3}\right]^{-}$ & 100 & 56 & 1 \\
\hline$[\mathrm{PETN}+\mathrm{Cl}]^{-}$ & 100 & 100 & 100 \\
\hline$\left[\mathrm{PETN}+\mathrm{NO}_{3}\right]^{-}$ & 32 & 1 & 1 \\
\hline [PETriN + Cl] $^{-}$ & 22 & 15 & 16 \\
\hline$\left[\mathrm{PEDiN}+\mathrm{Cl}^{-}\right.$ & 6 & 4 & 6 \\
\hline
\end{tabular}


Table 4. Prominent ETN fragments by GC/MS and their assignments

\begin{tabular}{c|c}
$\boldsymbol{m} / \boldsymbol{z}$ & Fragment \\
\hline 30 & $\mathrm{NO}, \mathrm{CH}_{2} \mathrm{O}$ \\
\hline 46 & $\mathrm{NO}_{2}$ \\
\hline 60 & $\mathrm{CH}_{2} \mathrm{NO}_{2}$ \\
\hline 76 & $\mathrm{CH}_{2} \mathrm{NO}_{3}$ \\
\hline 89 & $\mathrm{C}_{2} \mathrm{H}_{3} \mathrm{NO}_{3}$ \\
\hline 118 & $\mathrm{C}_{2} \mathrm{H}_{2} \mathrm{~N}_{2} \mathrm{O}_{4}$ \\
\hline 151 & $\mathrm{C}_{2} \mathrm{H}_{2} \mathrm{~N}_{2} \mathrm{O}_{6}$
\end{tabular}

Table 5. DSC Results for ETN, PETN, DNTN at various scan rates

\begin{tabular}{|c|c|c|c|c|c|c|c|c|}
\hline & $\begin{array}{c}\beta \\
(K / \min )\end{array}$ & $\mathrm{n}=$ & $\begin{array}{l}\text { mass } \\
(\mathrm{mg})\end{array}$ & $\begin{array}{c}\text { Endotherm } \\
T_{\min }\left({ }^{\circ} \mathrm{C}\right)\end{array}$ & $\begin{array}{l}\Delta H_{\text {fus }} \\
(\mathrm{J} / \mathrm{g})\end{array}$ & $\begin{array}{l}\text { Exotherm } \\
\text { onset }\left({ }^{\circ} \mathrm{C}\right)\end{array}$ & $\begin{array}{c}\text { Exotherm } \\
\mathrm{T}_{\max }\left({ }^{\circ} \mathrm{C}\right)\end{array}$ & $\begin{array}{c}\Delta \mathrm{H} \\
(\mathrm{J} / \mathrm{g})\end{array}$ \\
\hline \multirow[t]{11}{*}{ PETN } & 20 & 4 & 0.125 & 144 & 109 & 198 & 212 & 1971 \\
\hline & 10 & 4 & 0.297 & 143 & 148 & 193 & 202 & 3874 \\
\hline & 9 & 3 & 0.280 & 143 & 128 & 192 & 201 & 3358 \\
\hline & 8 & 4 & 0.298 & 142 & 147 & 191 & 199 & 4032 \\
\hline & 7 & 3 & 0.330 & 142 & 145 & 188 & 196 & 3634 \\
\hline & 6 & 3 & 0.326 & 142 & 117 & 189 & 195 & 4060 \\
\hline & 5 & 3 & 0.284 & 143 & 110 & 186 & 194 & 3734 \\
\hline & 4 & 3 & 0.289 & 142 & 117 & 183 & 192 & 2985 \\
\hline & 3 & 3 & 0.282 & 141 & 102 & 181 & 189 & 2919 \\
\hline & 2 & 3 & 0.301 & 140 & 120 & 178 & 183 & 3553 \\
\hline & 1 & 3 & 0.352 & 140 & 137 & 172 & 173 & 4096 \\
\hline \multirow[t]{11}{*}{ ETN } & 20 & 4 & 0.203 & 60 & 113 & 184 & 199 & 2233 \\
\hline & 10 & 5 & 0.200 & 62 & 107 & 182 & 193 & 2795 \\
\hline & 9 & 6 & 0.288 & 63 & 105 & 183 & 192 & 2592 \\
\hline & 8 & 5 & 0.244 & 63 & 102 & 182 & 191 & 2437 \\
\hline & 7 & 4 & 0.255 & 61 & 117 & 182 & 186 & 3181 \\
\hline & 6 & 1 & 0.232 & 63 & 102 & 181 & 185 & 2418 \\
\hline & 5 & 2 & 0.226 & 59 & 116 & 176 & 180 & 3253 \\
\hline & 4 & 2 & 0.219 & 62 & 104 & 176 & 180 & 2948 \\
\hline & 3 & 3 & 0.255 & 60 & 114 & 171 & 173 & 2957 \\
\hline & 2 & 2 & 0.281 & 61 & 99 & 168 & 169 & 2551 \\
\hline & 1 & 6 & 0.292 & 59 & 109 & 155 & 156 & 3130 \\
\hline \multirow[t]{11}{*}{ DNTN } & 20 & 4 & 0.311 & 88 & 135 & 179 & 185 & 3185 \\
\hline & 10 & 3 & 0.279 & 87 & 71 & 170 & 175 & 3121 \\
\hline & 9 & 2 & 0.381 & 87 & 99 & 167 & 171 & 3756 \\
\hline & 8 & 3 & 0.338 & 86 & 70 & 165 & 169 & 3116 \\
\hline & 7 & 2 & 0.354 & 85 & 50 & 166 & 169 & 2730 \\
\hline & 6 & 1 & 0.313 & 85 & 80 & 163 & 167 & 3855 \\
\hline & 5 & 3 & 0.223 & 84 & 70 & 159 & 163 & 2809 \\
\hline & 4 & 3 & 0.433 & 85 & 80 & 155 & 158 & 3934 \\
\hline & 3 & 2 & 0.400 & 86 & 89 & 150 & 154 & 3342 \\
\hline & 2 & 3 & 0.311 & 86 & 87 & 151 & 149 & 3257 \\
\hline & 1 & 3 & 0.250 & 84 & 81 & 141 & 142 & 3342 \\
\hline
\end{tabular}


Table 6. Summary of experimentally measured physical properties: DSC \& activation energies, vapor pressure, sublimation enthalpies, densities, drop weight impact.

\begin{tabular}{|c|c|c|c|}
\hline & DNTN & ETN & PETN \\
\hline & $\mathrm{C}_{6} \mathrm{H}_{8} \mathrm{~N}_{6} \mathrm{O}_{16}$ & $\mathrm{C}_{4} \mathrm{H}_{6} \mathrm{~N}_{4} \mathrm{O}_{12}$ & $\mathrm{C}_{5} \mathrm{H}_{8} \mathrm{~N}_{4} \mathrm{O}_{12}$ \\
\hline melting points ${ }^{\circ} \mathrm{C}$ & $85-86$ & $60-61$ & 143 \\
\hline Heat release obs by DSC $(\mathrm{J} / \mathrm{g})$ & 3200 & 2800 & 3900 \\
\hline DSC Exo $T_{\text {max }}$ at $20^{\circ} \mathrm{C} / \mathrm{min}$ & $184^{\circ} \mathrm{C}$ & $200^{\circ} \mathrm{C}$ & $212^{\circ} \mathrm{C}$ \\
\hline DSC Exo $T_{\max }$ at $10^{\circ} \mathrm{C} / \mathrm{min}$ & $174^{\circ} \mathrm{C}$ & $193^{\circ} \mathrm{C}$ & $202^{\circ} \mathrm{C}$ \\
\hline DTA (max. mass loss $10^{\circ} / \mathrm{min}$ ) & $180^{\circ} \mathrm{C}$ & $200^{\circ} \mathrm{C}$ & $200^{\circ} \mathrm{C}$ \\
\hline $\mathrm{Ea}(\mathrm{kJ} / \mathrm{mol})$ & 96.3 & 95.0 & 136.5 \\
\hline$A\left(s^{-1}\right)$ & $1.03 \times 10^{11}$ & $2.35 \times 10^{10}$ & $7.47 \times 10^{14}$ \\
\hline Vapor Pressure $(\mathrm{Pa}), 25^{\circ} \mathrm{C}$ & $4.10 \times 10^{-3}$ & $3.19 \times 10^{-3}$ & $5.21 \times 10^{-6}$ \\
\hline$\Delta \mathrm{H}_{\text {sub }}(\mathrm{kJ} / \mathrm{mol})$ & 105.3 & 117.7 & 146.6 \\
\hline Pycnometer Density $\left(\mathrm{g} / \mathrm{cm}^{3}\right)$ & 1.8238 & 1.7219 & 1.7599 \\
\hline Literature $X$-ray density $\left(\mathrm{g} / \mathrm{cm}^{3}\right)$ & $1.917^{9}$ & $1.55^{3}$ & $1.778^{28}$ \\
\hline Drop Wt $(4 \mathrm{Kg})$ Impact $\mathrm{Dh}_{50}(\mathrm{~cm})$ & 27.7 & 24.0 & 25.2 \\
\hline
\end{tabular}


Table 7. Summary of small-scale explosivity device results.

\begin{tabular}{|c|c|c|c|c|c|}
\hline Sample & $\begin{array}{l}\text { Charge } \\
\text { depth } \\
(\mathrm{mm})\end{array}$ & $\begin{array}{c}\text { Tap } \\
\text { Density } \\
(\mathrm{g} / \mathrm{mL})\end{array}$ & $\begin{array}{c}\text { Mass } \\
\text { Cartridge } \\
\text { (g) }\end{array}$ & $\begin{array}{c}\text { Mass } \\
\text { Remaining } \\
\text { (g) }\end{array}$ & $\begin{array}{c}\text { fraction } \\
\text { remaining } \\
(\%,(S D))\end{array}$ \\
\hline ETN 1 & 18 & 0.71 & 11.027 & 3.0412 & 27.6 \\
\hline ETN 2 & 25 & 0.91 & 10.9242 & 3.0325 & 27.8 \\
\hline ETN 3 & 9 & 0.58 & 11.1935 & 3.1628 & 28.3 \\
\hline ETN 4 & 14 & 0.64 & 11.2962 & 2.994 & 26.5 \\
\hline ETN 5 & 29 & 1.07 & 10.987 & 3.3665 & 30.6 \\
\hline ETN 6 & 30 & 1.07 & 11.2383 & 3.1386 & 27.9 \\
\hline Average & & & & & $28.1(1.4)$ \\
\hline PETN 1 & 17 & 0.69 & 11.0747 & 2.8792 & 26 \\
\hline PETN 2 & 14 & 0.64 & 11.183 & 2.9109 & 26 \\
\hline PETN 3 & 18 & 0.71 & 11.3524 & 3.0374 & 26.8 \\
\hline Average & & & & & $26.3(0.4)$ \\
\hline DNTN 1 & 21 & 0.77 & 11.1826 & 2.7519 & 24.6 \\
\hline DNTN 2 & 17 & 0.69 & 11.1314 & 2.9157 & 26.2 \\
\hline DNTN 3 & 20 & 0.77 & 11.4555 & 2.9974 & 26.2 \\
\hline DNTN 4 & 26 & 0.91 & 11.3384 & 2.7119 & 23.9 \\
\hline Average & & & & & $25.2(1.1)$ \\
\hline RDX 1 & 30 & 1.07 & 11.3428 & 1.4285 & 12.6 \\
\hline RDX 2 & 30 & 1.07 & 11.208 & 1.3939 & 12.4 \\
\hline RDX 3 & 30 & 1.07 & 11.1956 & 1.1714 & 10.5 \\
\hline Average & & & & & $11.8(1.2)$ \\
\hline
\end{tabular}

Table 8. Summary of physical properties and performance

\begin{tabular}{|c|c|c|c|c|c|}
\hline & EGDN & DNTN & ETN & PETN & RDX \\
\hline chemical formula & $\mathrm{C}_{2} \mathrm{H}_{4} \mathrm{~N}_{2} \mathrm{O}_{6}$ & $\mathrm{C}_{6} \mathrm{H}_{8} \mathrm{~N}_{6} \mathrm{O}_{16}$ & $\mathrm{C}_{4} \mathrm{H}_{6} \mathrm{~N}_{4} \mathrm{O}_{12}$ & $\mathrm{C}_{5} \mathrm{H}_{8} \mathrm{~N}_{4} \mathrm{O}_{12}$ & $\mathrm{C}_{3} \mathrm{H}_{6} \mathrm{~N}_{6} \mathrm{O}_{6}$ \\
\hline molecular weight $(\mathrm{g} / \mathrm{mol})$ & 152 & 420 & 302 & 316 & 222 \\
\hline Oxygen Balance $\left(\%\right.$ to $\left.\mathrm{CO}_{2}\right)$ & 0 & 0 & 5.3 & -10.1 & -21.6 \\
\hline melting point ${ }^{\circ} \mathrm{C}$ (measured) & -22 & $85-86$ & 61 & 143 & 204 \\
\hline heat of formation $\mathrm{kcal} / \mathrm{mol}$ & -58.08 & -88.67 & -113.48 & -128.7 & -16.73 \\
\hline Small Scale Explosivity \% rem & & 25.1 & 28.1 & 26.3 & 11.8 \\
\hline Stand. Dev & & 1.1 & 1.4 & 0.4 & 1.2 \\
\hline pycnometer density $\mathrm{g} / \mathrm{cm}^{3}$ & $1.492^{2}$ & 1.8238 & 1.7219 & 1.7599 & $1.767^{28}$ \\
\hline detonation velocity ${ }^{*} \mathrm{~km} / \mathrm{s}$ & 7.517 & 8.895 & 8.206 & 8.481 & 8.65 \\
\hline CJ pressure* GPa & 20.37 & 34.97 & 26.77 & 30.44 & 31.56 \\
\hline SSED density $\mathrm{g} / \mathrm{cm}^{3}$ & 0.69 & 0.69 & 0.69 & 0.69 & 0.69 \\
\hline detonation velocity ${ }^{*} \mathrm{~km} / \mathrm{s}$ & 4.198 & 4.187 & 3.998 & 4.293 & 4.738 \\
\hline CJ pressure* GPa & 3.594 & 3.597 & 3.274 & 3.717 & 4.443 \\
\hline
\end{tabular}

* Determined with Cheetah $6.0^{27}$ 
Figure 1. Raman Spectrum of (ETN).

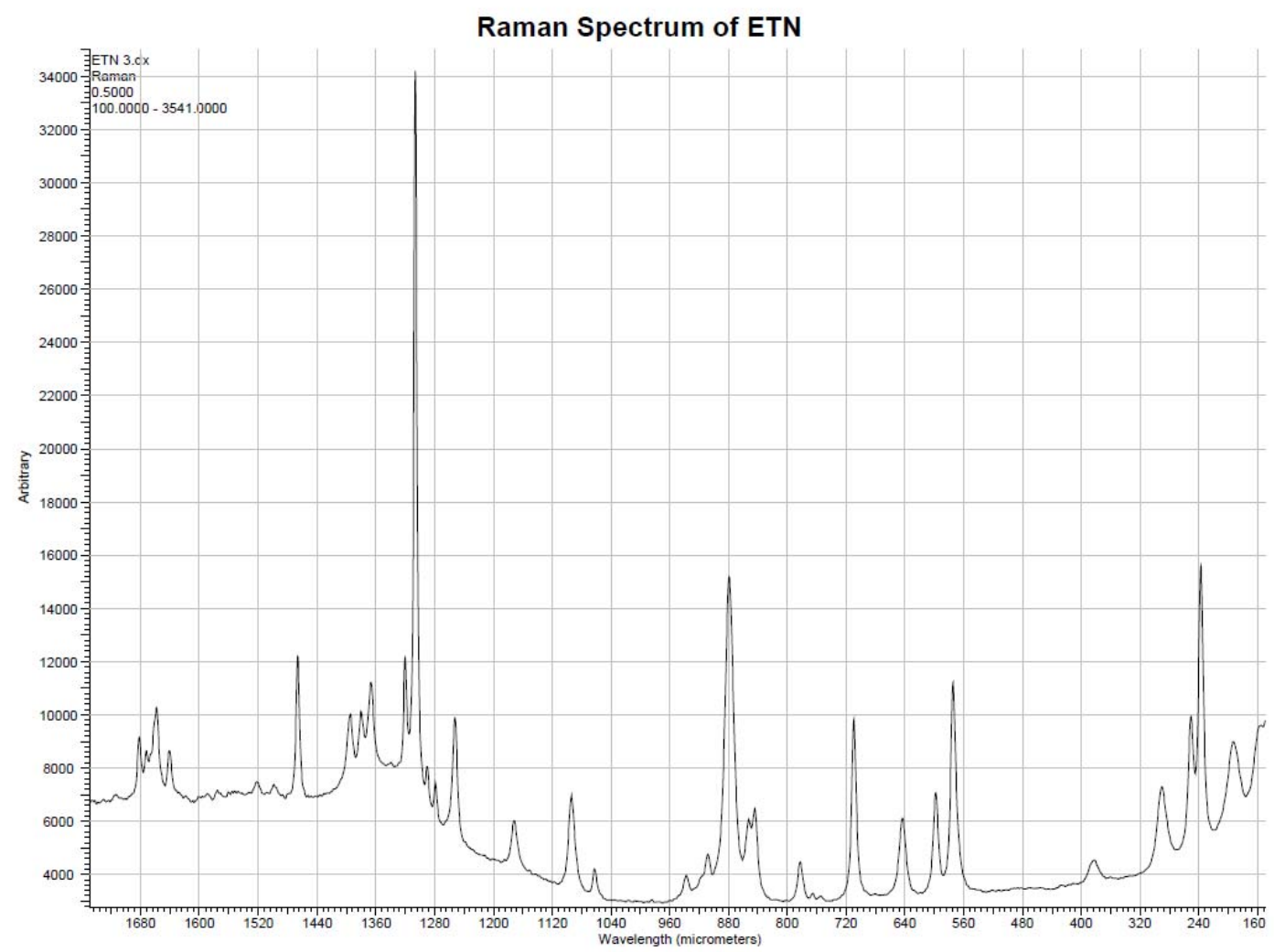


Figure 2. Infrared spectrum of ETN.

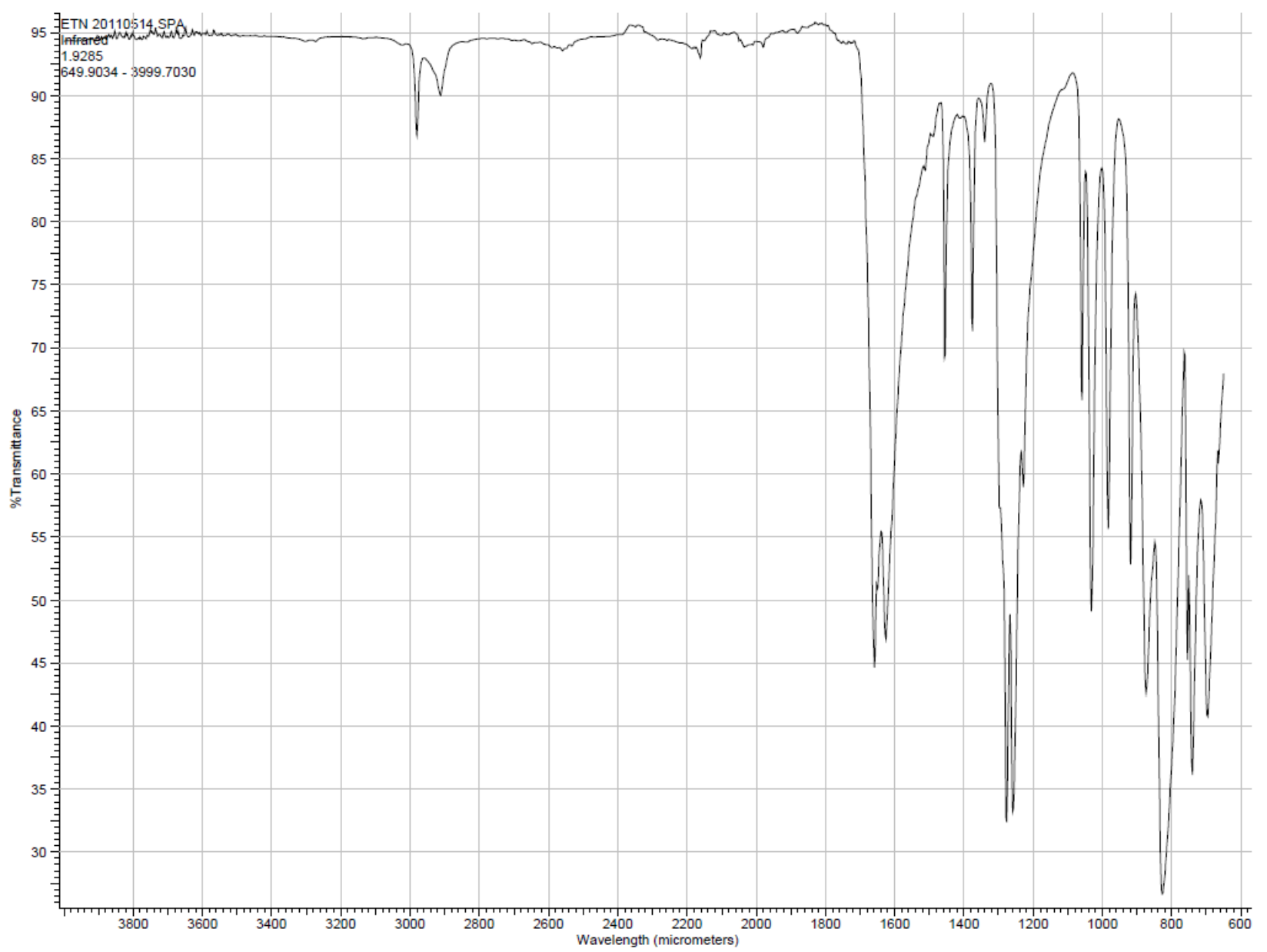


Figure 3. Raman Spectrum of DNTN.

\section{Raman Spectrum of DNTN}

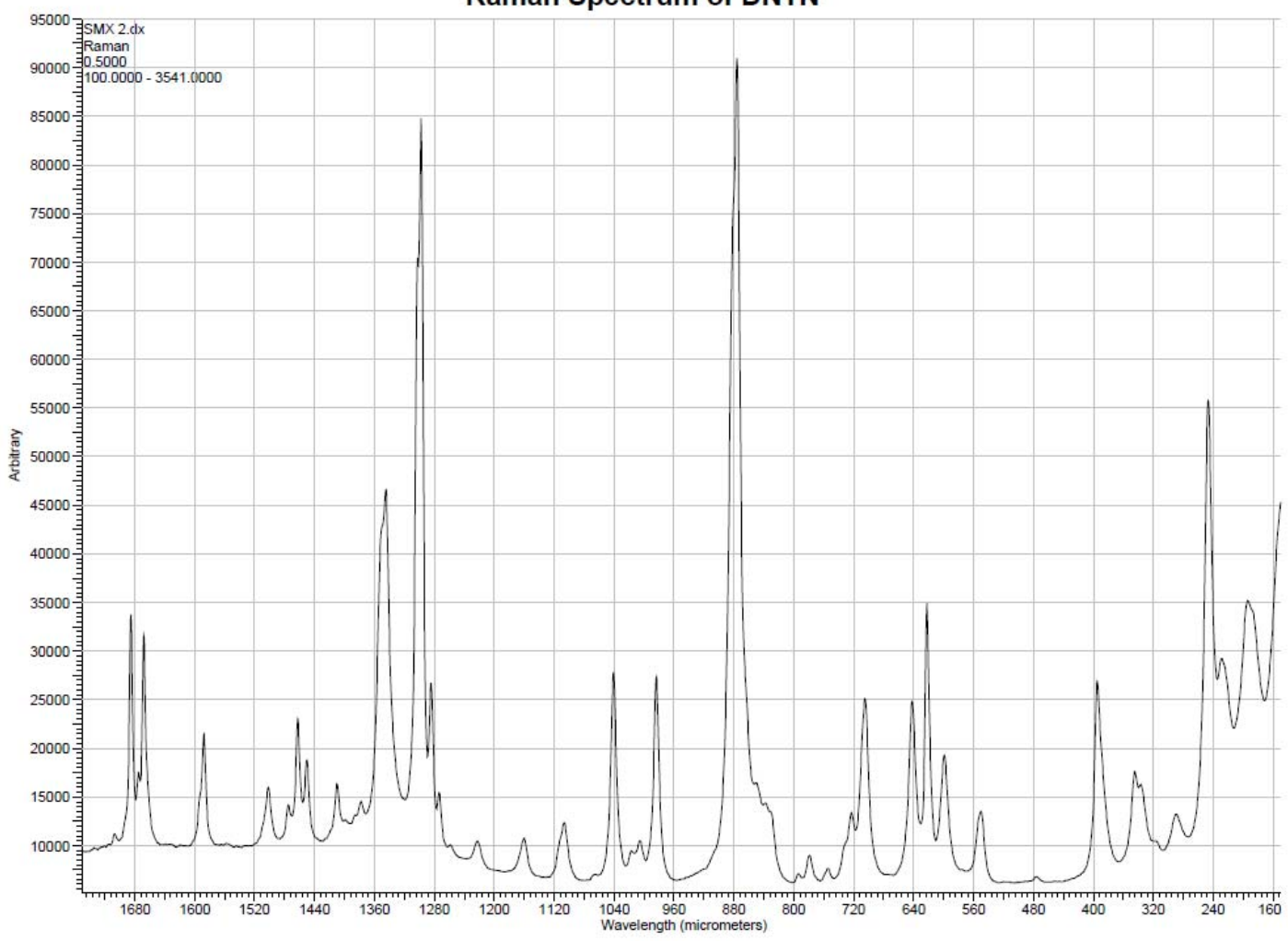


Figure 4. Infrared Spectrum of DNTN

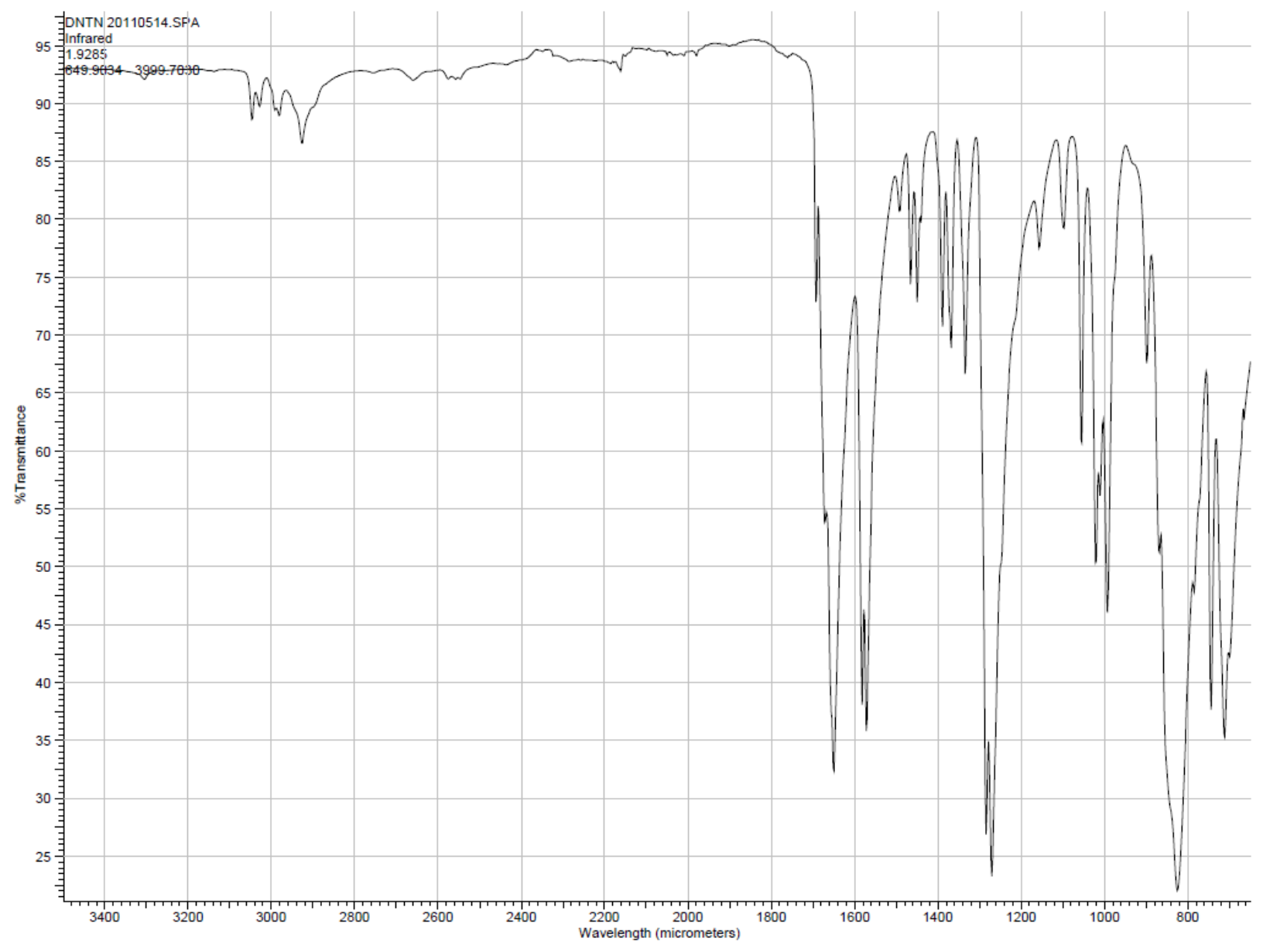


Figure 5. Mass spectra of ETN by direct injection (A), separated by HPLC (B) and EtriN (C).

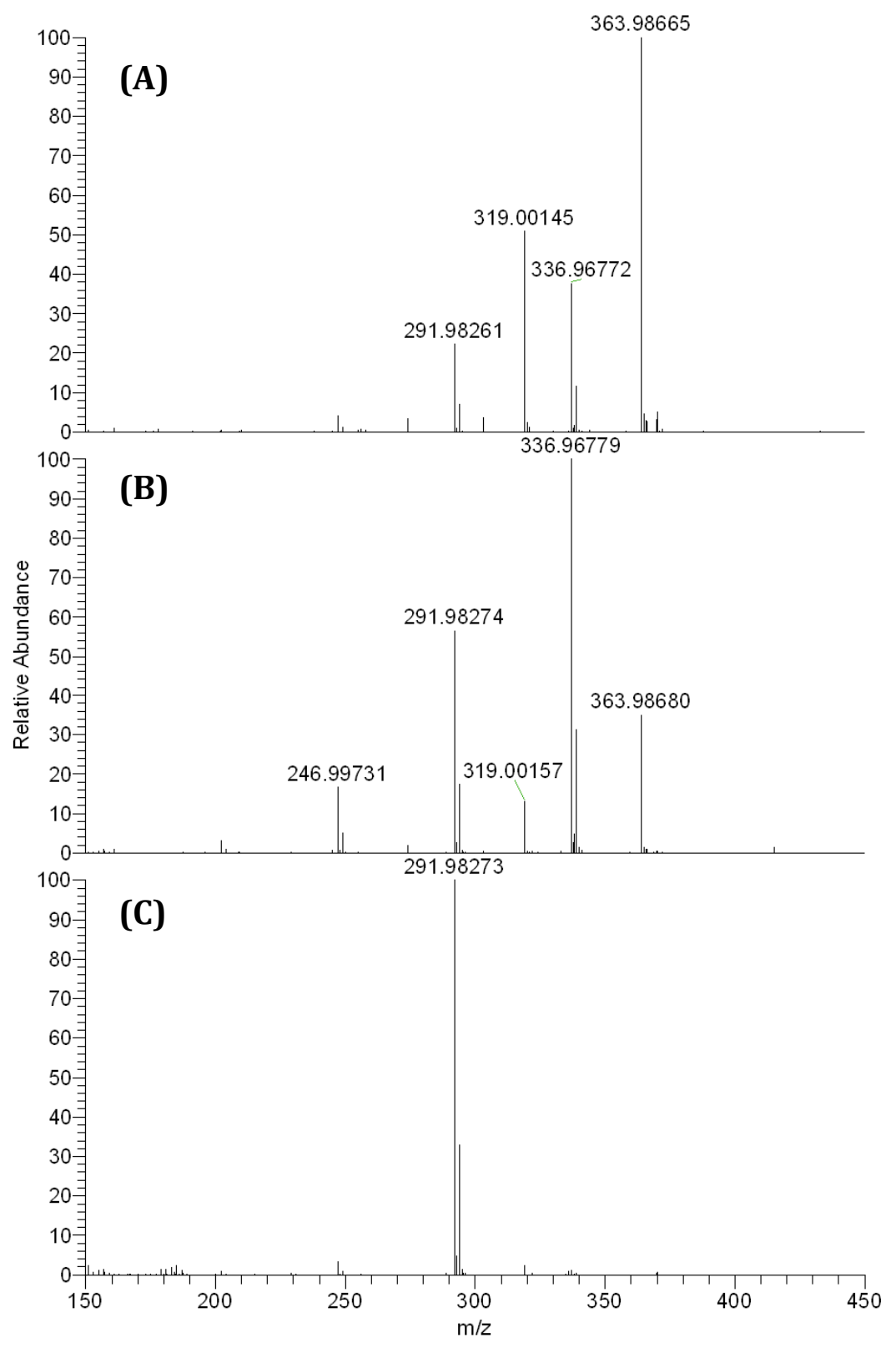


Figure 6. Chromatograms of recrystallized ETN (top) and crude ETN (bottom)

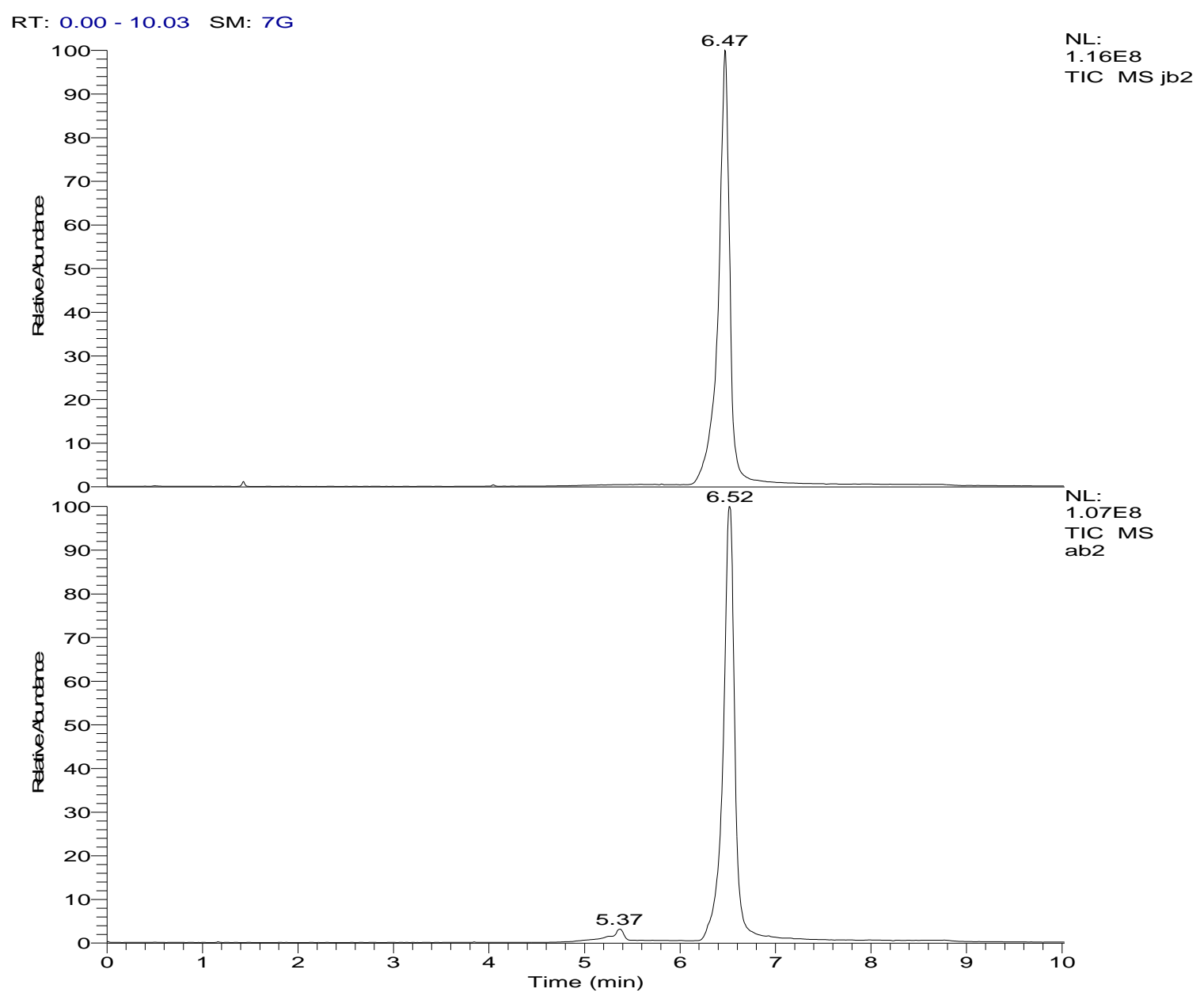


Figure 7. Comparison of gas chromatograms at inlet temperatures of $200^{\circ} \mathrm{C}$ (top) and $100^{\circ} \mathrm{C}$ (bottom). Abundance

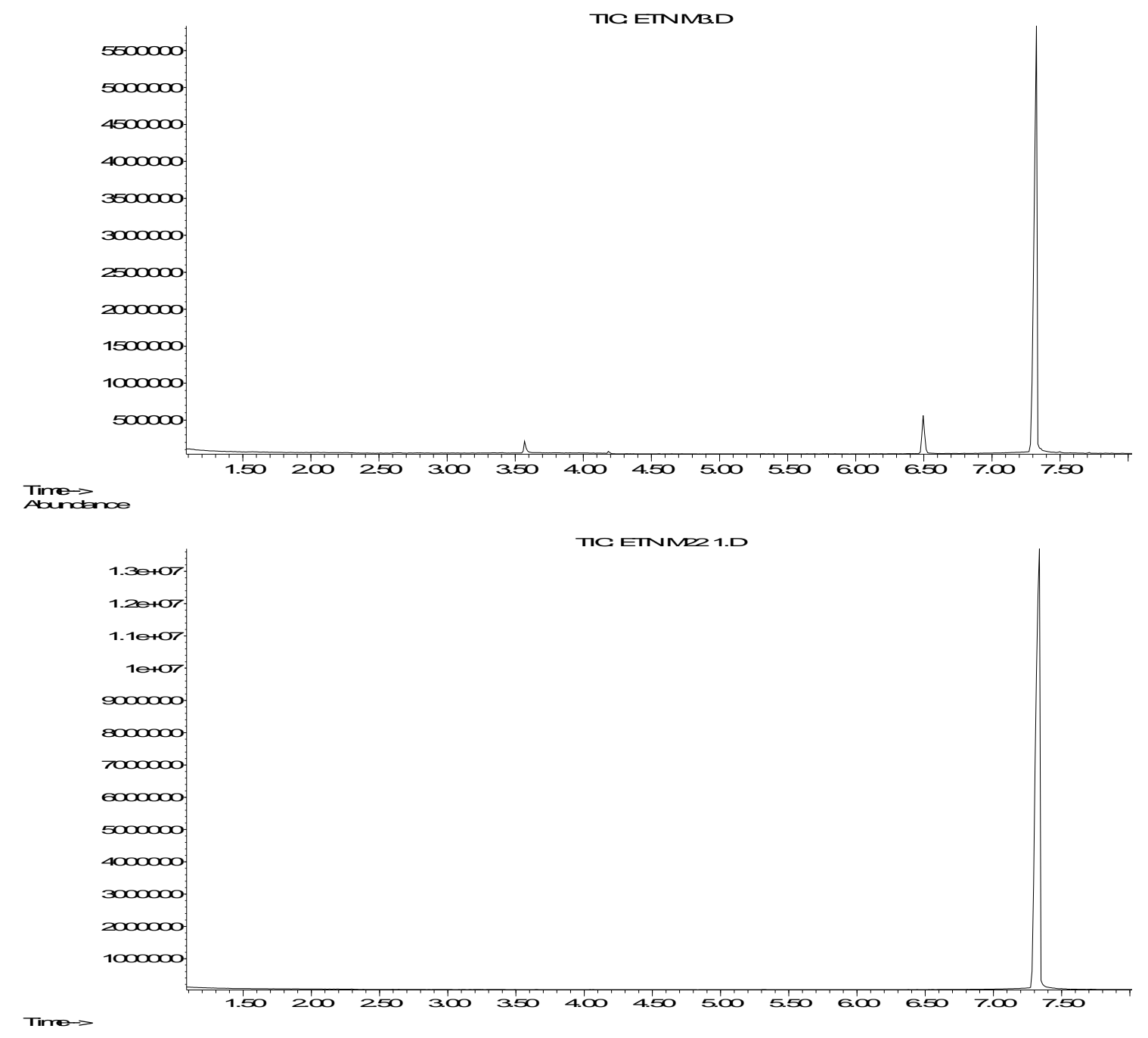


Figure 8. Thermogram of ETN at $10^{\circ} \mathrm{C} / \mathrm{min}$.

Sample: ETN 2R

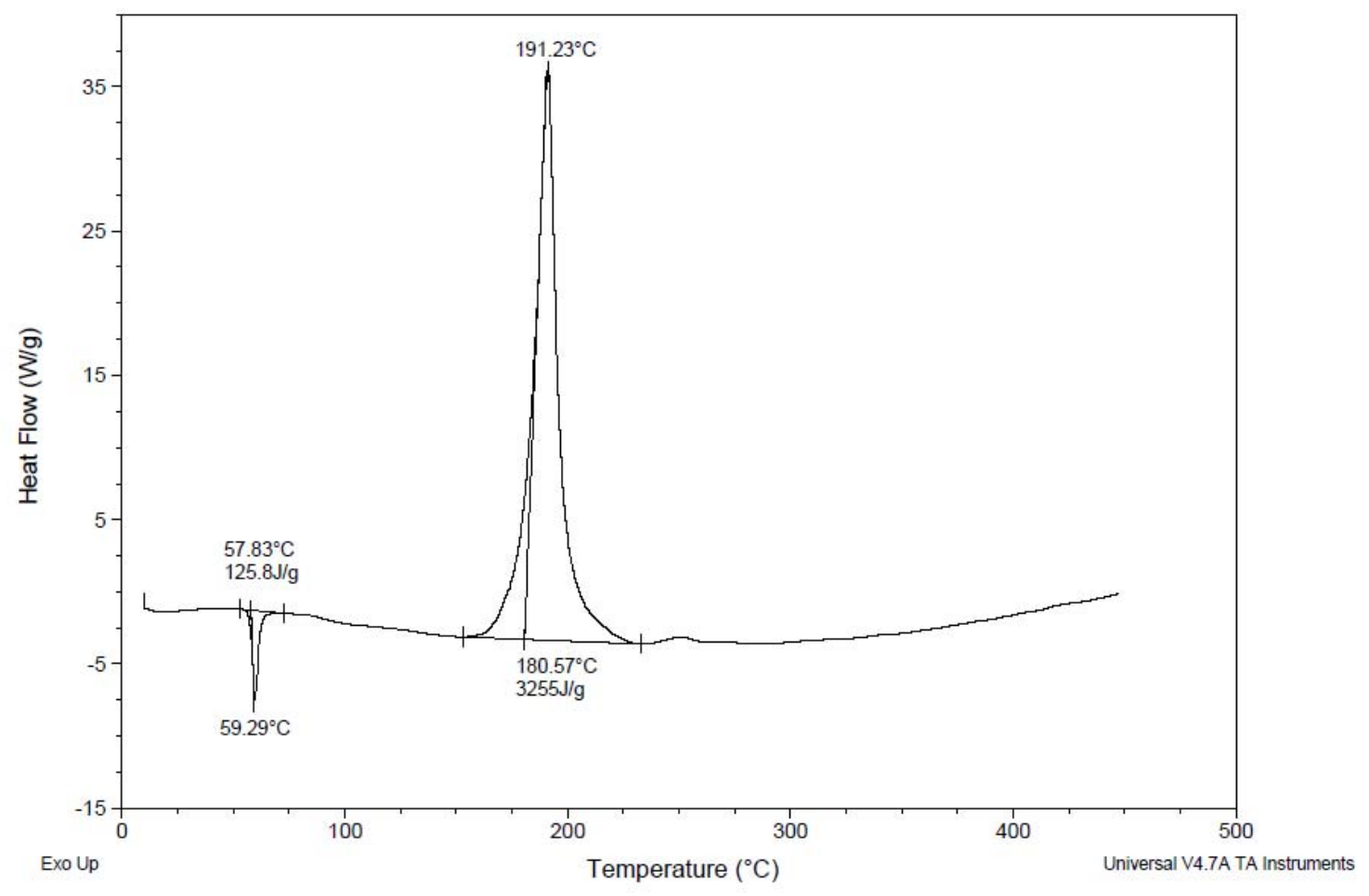


Figure 9. Thermogram of DNTN at $10^{\circ} \mathrm{C} / \mathrm{min}$.

Sample: DNTN

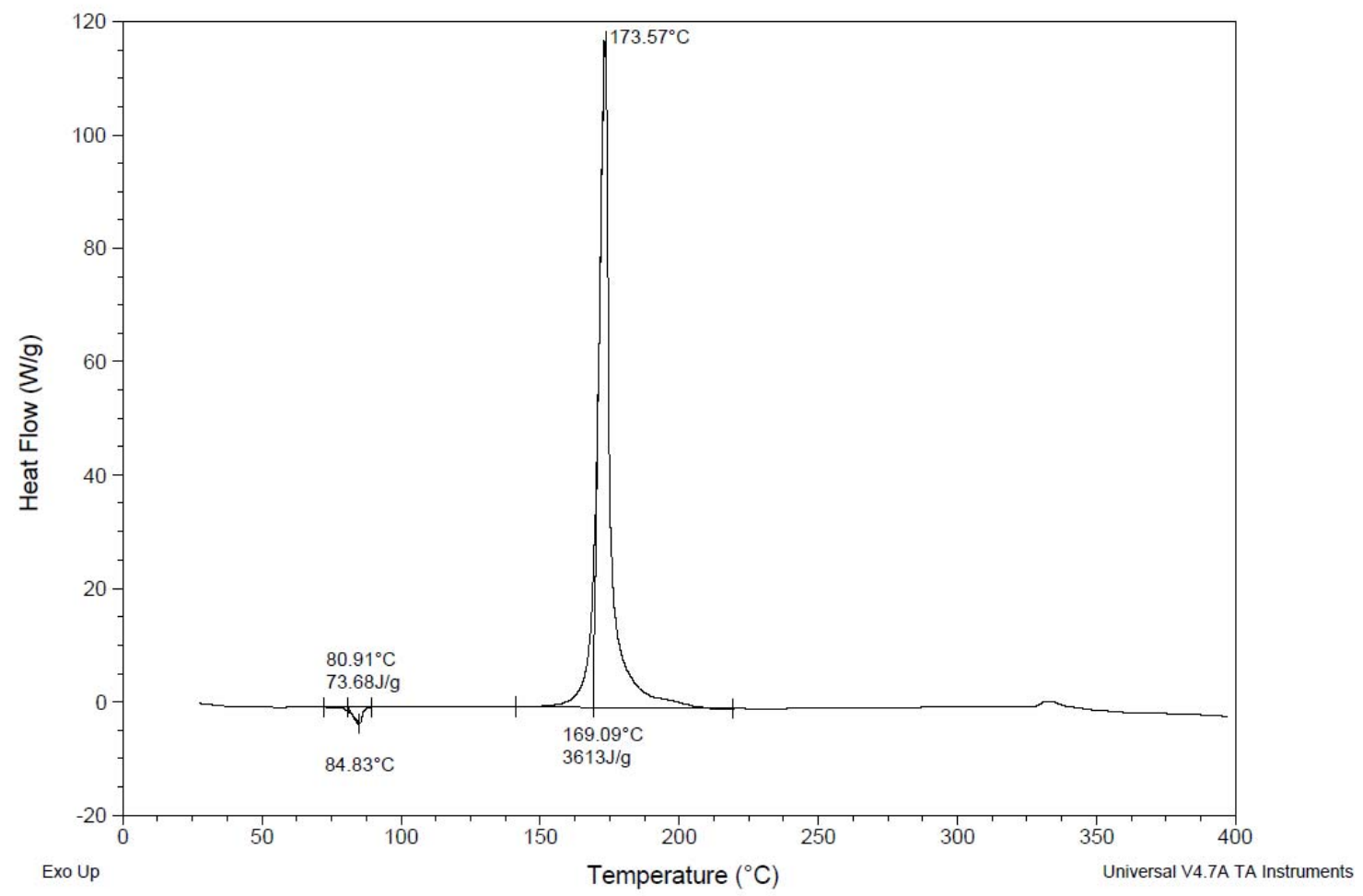


Figure 10 . Thermogram of PETN at $10^{\circ} \mathrm{C} / \mathrm{min}$.

Sample: PETN

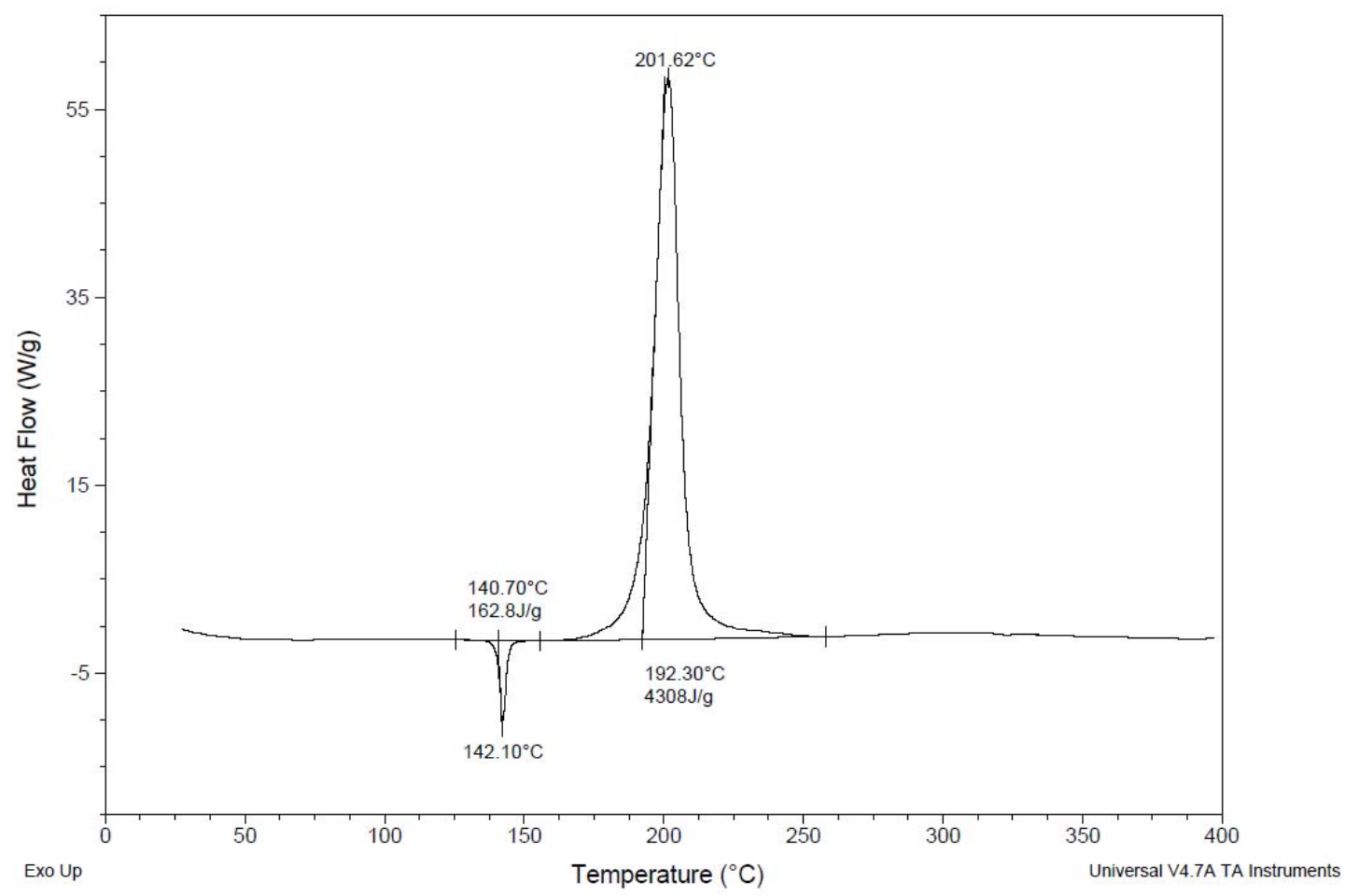


Figure 11. Plot for the determination of activation of ETN energy by DSC

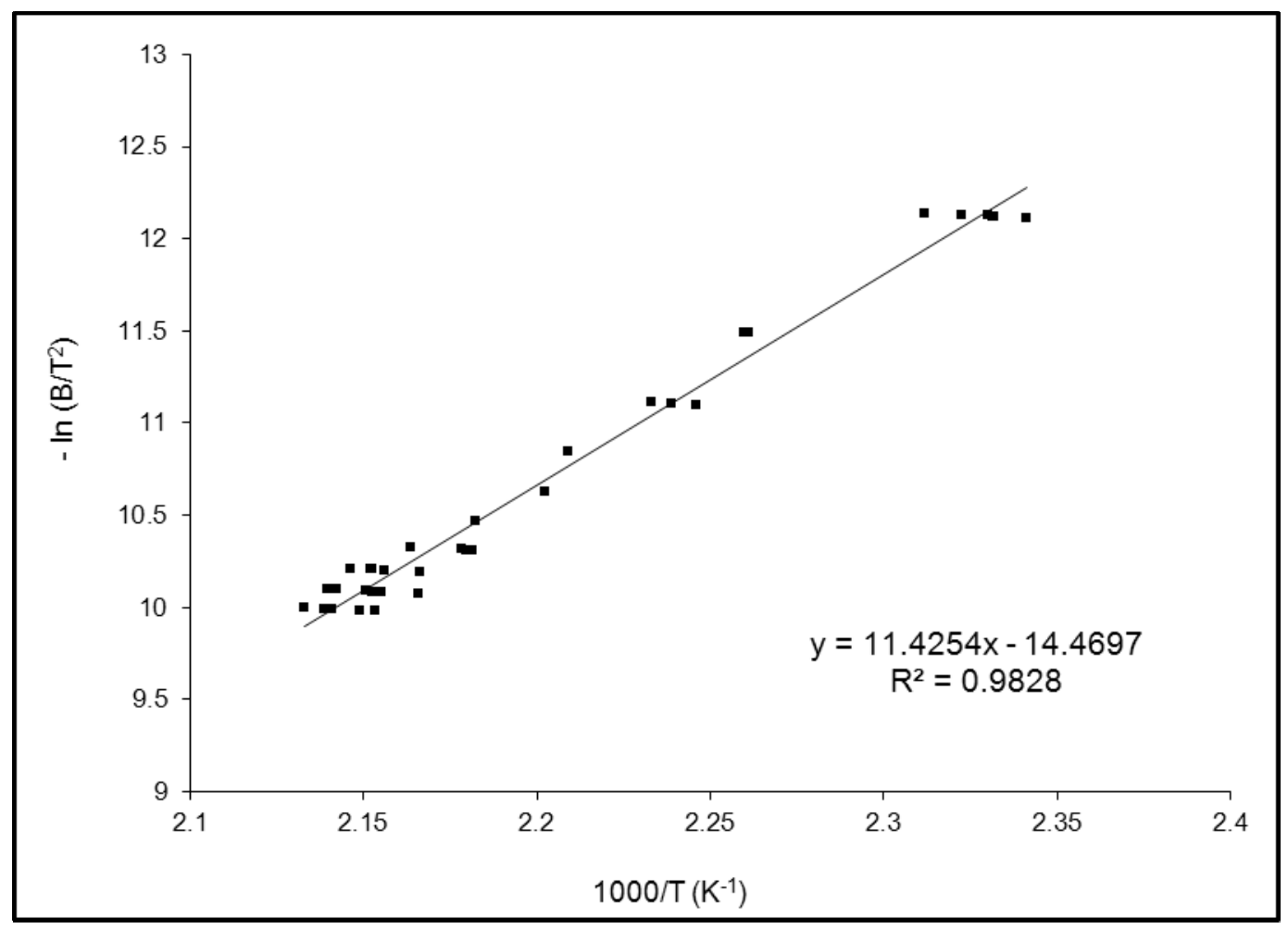


Figure 12. Plot for the determination of activation energy of DNTN by DSC

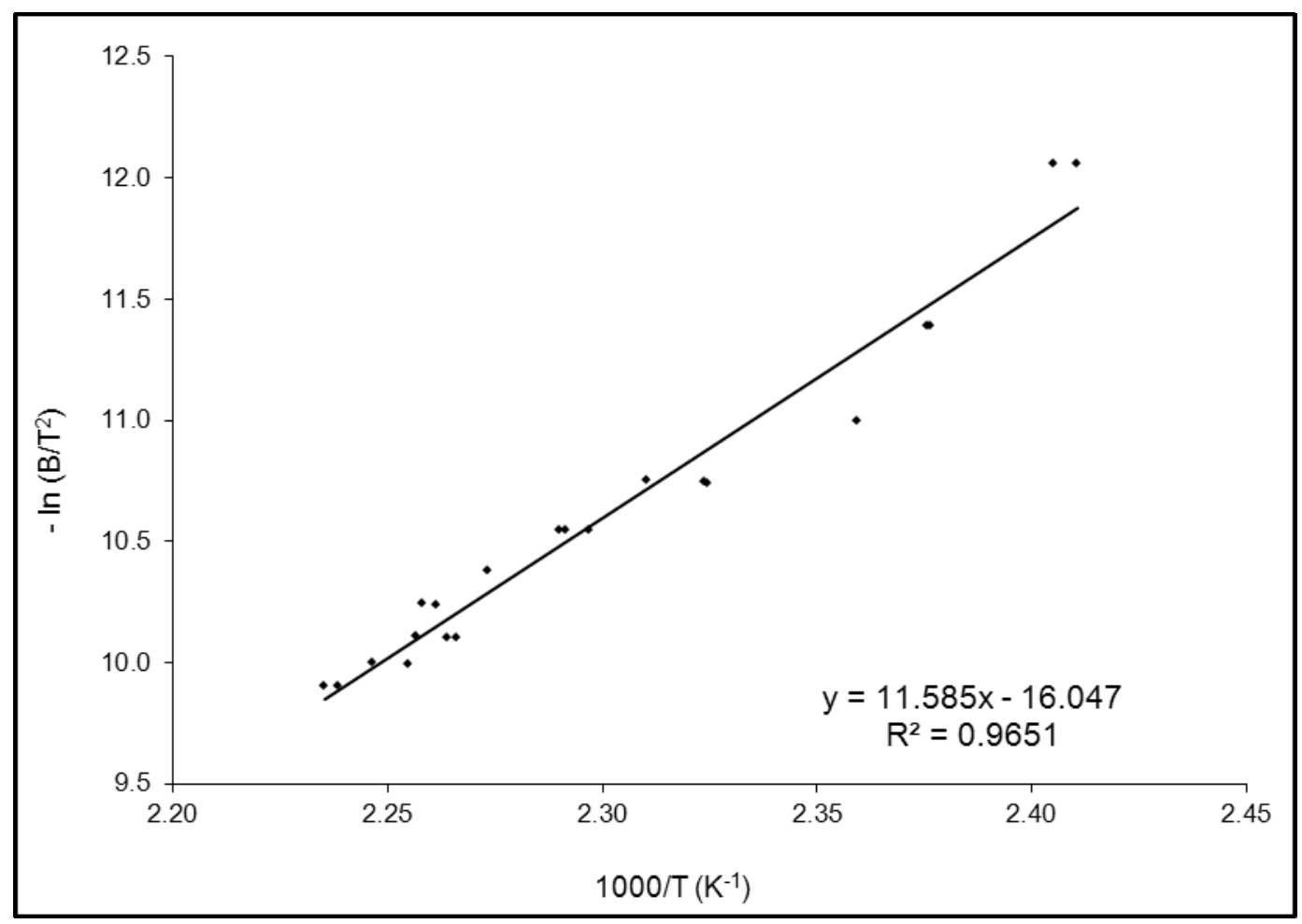


Figure 13. Plot for the determination of activation energy of PETN by DSC.

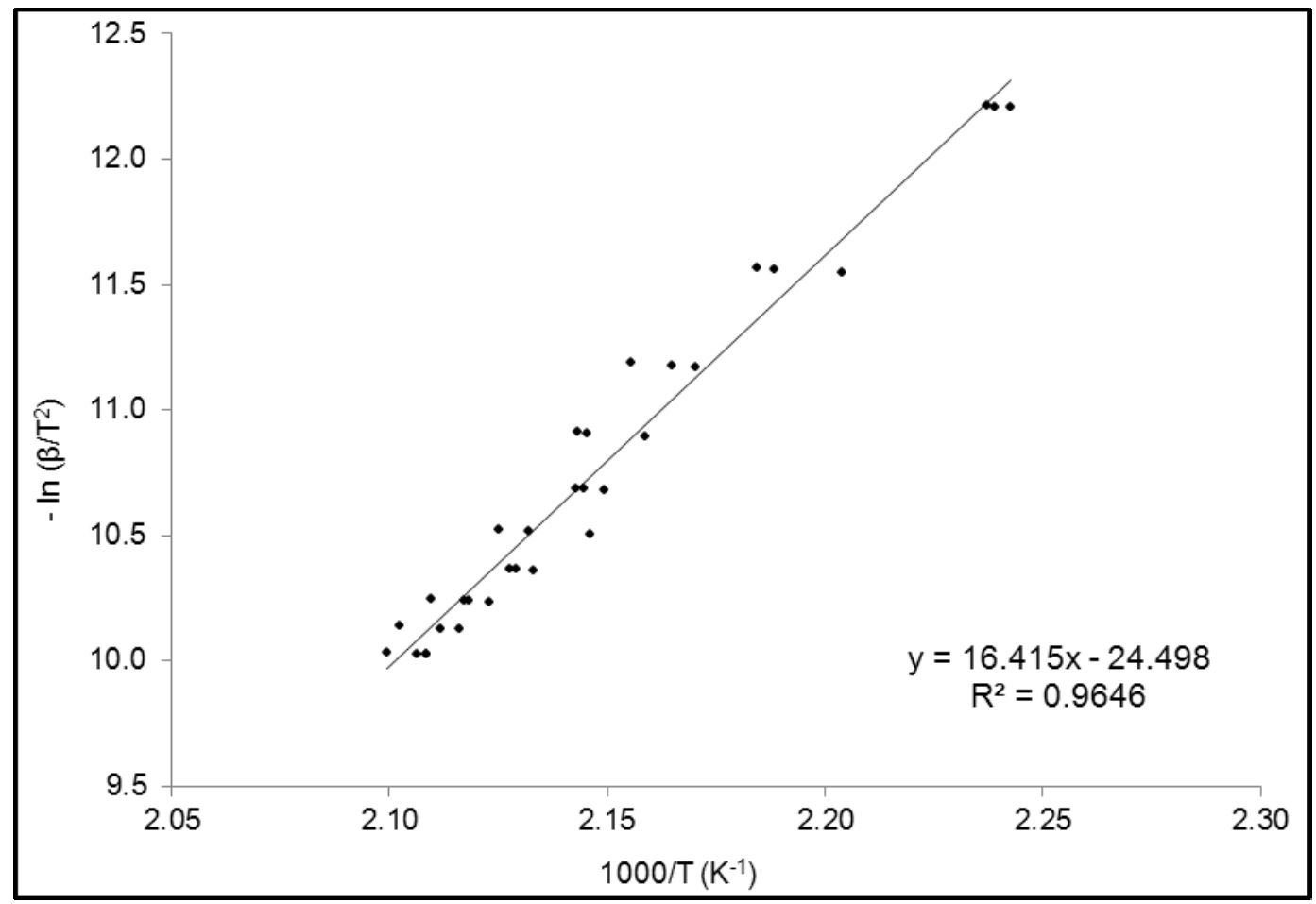


Figure 14. Thermogravimetric plots of ETN, PETN and DNTN

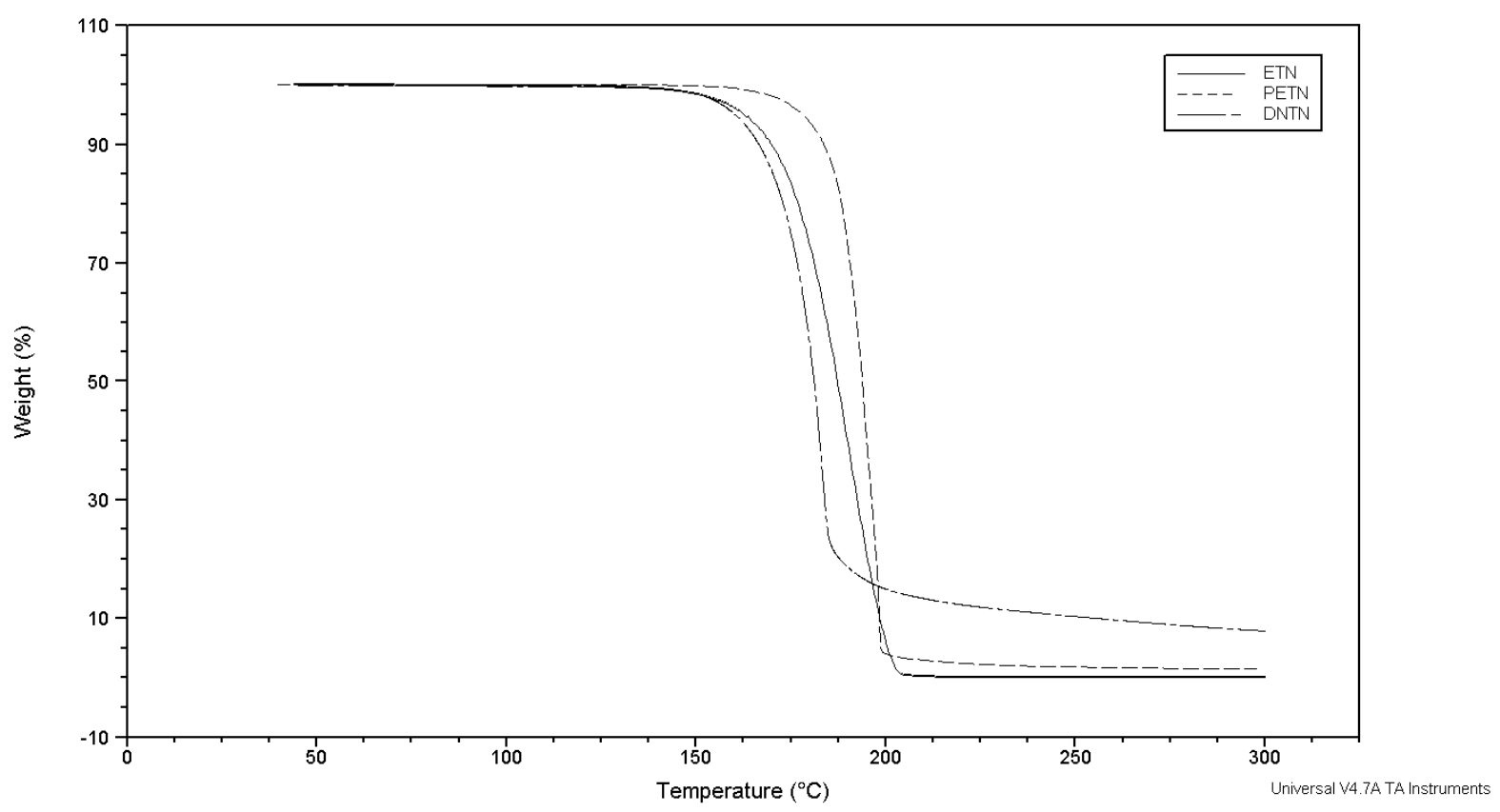

Figure 15. Plot of natural logarithm of the vapor pressure versus the natural logarithm of the sublimation rate for benzoic acid.

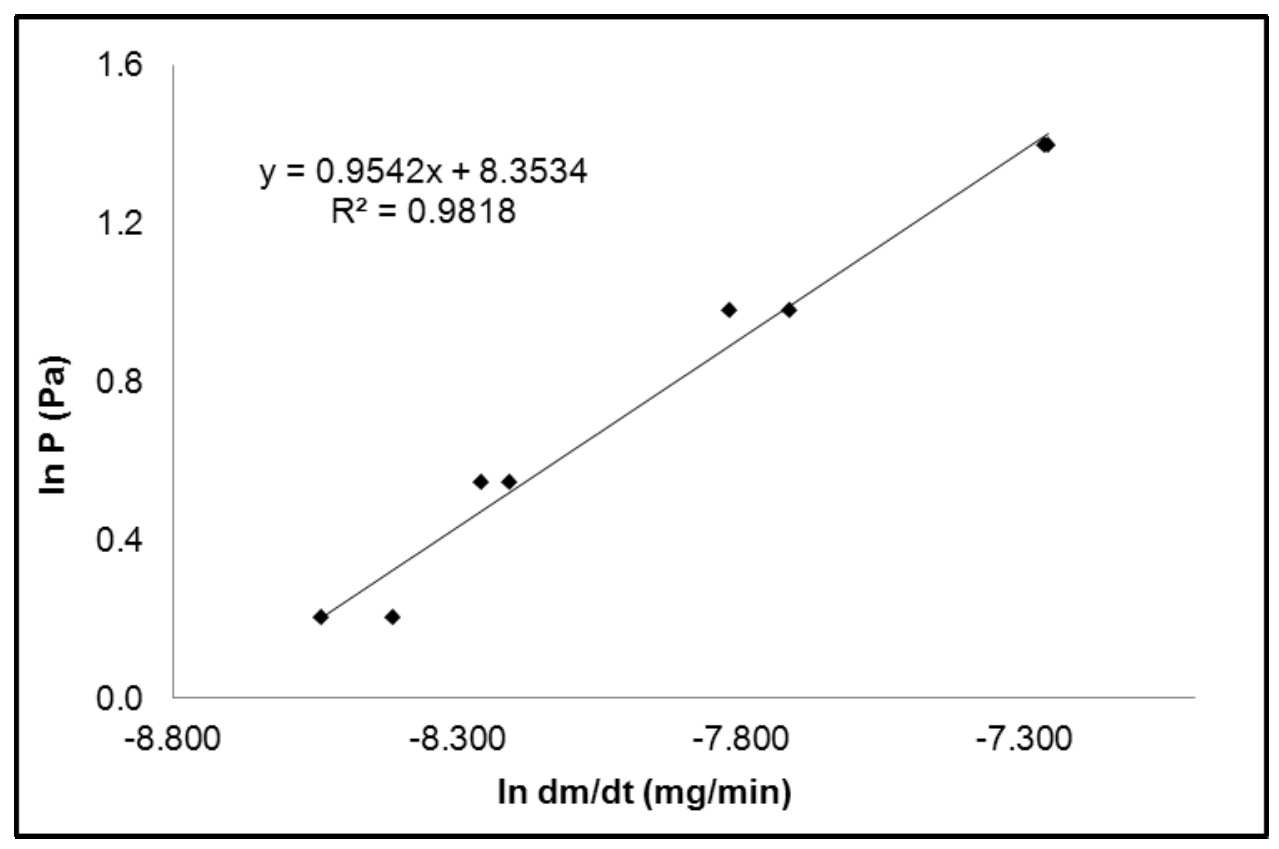


Figure 16. Claperyon plots for ETN and DNTN

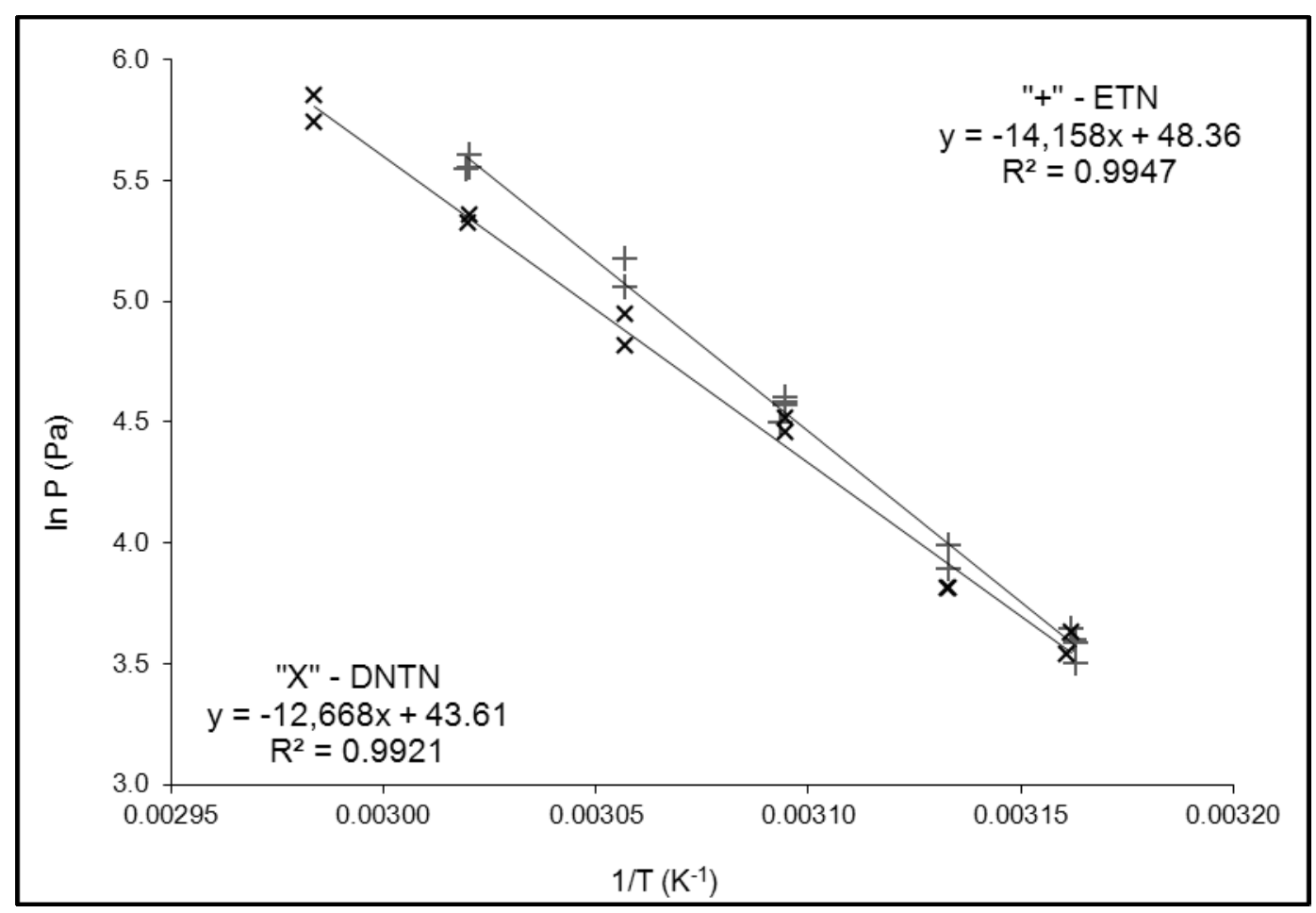


Figure 17. Claperyon plot for PETN.

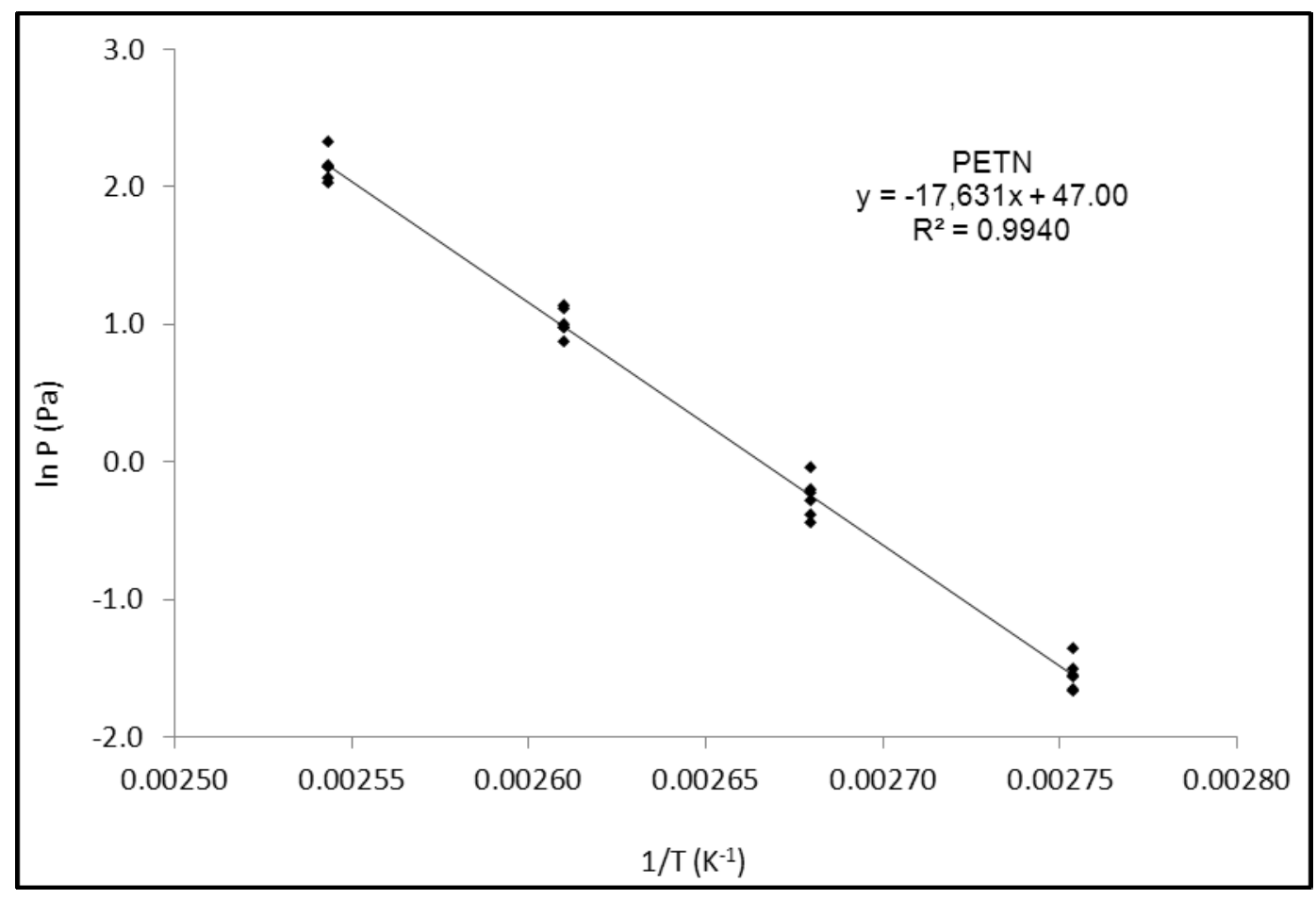

